\title{
Türkiye'de Ulusal Ormancılık Politikasının Tarihsel Gelişimi Açısından Bir Dönüm Noktası: 1255 Sayılı Yasa
}

\author{
Cihan ERDÖNMEZ1 ${ }^{1}$, Seçil YURDAKUL EROL ${ }^{1 *}$ \\ ${ }^{1}$ İstanbul Üniversitesi-Cerrahpaşa, Orman Fakültesi, Orman Mühendisliği Bölümü, 34473, Bahçeköy- \\ Sarıyer/İstanbul
}

\section{Öz}

Anayasa hem ormancılık politikası amaç ve araçlarının çatısını belirlemesi hem de bu araçlardan biri olması bakımından büyük önem taşımaktadır. Ülkemizde ormancılıkla ilgili kapsamlı bir içerik 1961 yılında yürürlüğe giren anayasada yer almıştır. Belirtilen anayasada; ormanların korunması, geliştirilmesi ve gözetiminin devletin görevi olduğu, devlet orman işletmeciliğinin esas olduğu hükümleri ile birlikte ormanların korunmasına yönelik bazı esaslara yer verilmiştir. Ancak bu yaklaşım uzun süre devam ettirilmemiş ve Anayasa'nın 131. maddesi 1970 yılında çıkarılan 1255 sayılı yasa ile değiştirilmiştir. Söz konusu değişiklik ile ülkede ormanların tahrip olmasına ve azalmasına neden olacak yaklaşımlar ve uygulamalar anayasa hükmü haline gelmiştir. Bu çalışmanın amacı, belirtilen yasanın hazırlanması ve yürürlüğe girmesi süreci ile ortaya çıkardığı sonuçları irdelemektir. Çalışmada literatür araştırması ve arşiv taraması ile elde edilen veriler doküman analizi yönteminden yararlanılarak değerlendirilmiştir. Elde edilen bulgular göstermektedir ki, belirtilen anayasa değişikliği toplumsal bir mutabakattan çok siyasi bir tercihin sonucudur. Bilim ve meslek camiası değişikliği kesinlikle onaylamamış, anayasa değişikliğinin TBMM'deki görüşmeleri aceleyle yapılmış, değişiklik yeterli şekilde tartışılmamıştır. Bu değişiklik, gerçekleşme süreci ve sonuçları açısından ulusal ormancılık politikasının dönüm noktalarından biri olmuştur.

Anahtar Kelimeler: Anayasa, Ormancılık, Ormancılık politikası, 1255 sayılı yasa.

\section{A Milestone in terms of Historical Development of the National Forestry Policy in Turkey: Law No. 1255}

\begin{abstract}
National constitution is of great importance in terms of both determining the framework of forestry policy objectives and tools and also being one of these tools. Comprehensive content on forestry was included in the Turkish constitution that entered into force in 1961. Conserving, improving and controlling of the forests was determined as duties of the state, state forest management is determined as the main principle and some principles regarding forest conservation was determined in this constitution. However, this approach was not maintained for a long time and the $131^{\text {st }}$ article of the constitution was replaced by the law numbered 1255 of 1970. The approaches and implementations that cause destruction of forests and deforestation became as a constitutional provision. The aim of the research was to examine the preparation and enactment processes of the law and its results. The data were collected from literature and archive-based researches and analyzed by document analysis. The findings showed that the amendment of the constitution was a result of political choice rather than a social consensus. The scientific and job-related bodies have definitely not approved the change, the negotiations of the constitutional amendment in the Turkish Grand National Assembly were made hastily and it was not adequately discussed. This amendment has been one of the turning points of national forest policy in terms of realization process and results.
\end{abstract}

Keywords: Constitution, Forestry, Forest policy, Law numbered 1255.

\footnotetext{
*Sorumlu Yazar (Corresponding Author):

Seçil YURDAKUL EROL (Doç. Dr.); İstanbul Üniversitesi-Cerrahpaşa, Orman 


\section{Giriş}

Ormancılık politikası, orman kaynakları ile toplum arasındaki ilişkileri içeren, bu ilişkiler çerçevesinde ülke düzeyinde ormancılık amaçlarını belirleyen ve bu amaçların gerçekleştirilmesi için gerekli önlemleri alan bir disiplindir (Gümüş, 2004; Akesen vd., 2010). Tanımdan da anlaşılacağı üzere ormancılık politikasının özünde toplumun orman kaynaklarından beklentileri ile orman kaynaklarının verebildikleri yatar. Bu ikisi arasında denge sağlanabilirse ormanların sürekliliği güvence altına alınmış olur. Ne var ki günümüz toplum yapısı ve özellikle kapitalist ekonomi anlayışı ihtiyaçların sınırsızlığı üzerinde şekillenmektedir. Aslında sınırsız olan ihtiyaçlar değil isteklerdir. Kapitalist ekonominin şekillendirdiği toplumlarda istekler ihtiyaç olarak öne sürülür ve sürekli artan bu istekleri karşılamak için çareler aranır. Ancak hemen bütün isteklerin karşılanması doğrudan ya da dolaylı olarak doğal kaynaklar ve ormanlar üzerinde bir yük oluşturur.

Nüfusun az, isteklerin sınırlı olduğu dönemlerde ormanlar üzerindeki baskı fark edilmemiştir. Türkiye'de, tarihsel süreçte 1870 yılında çıkarılan Orman Nizamnamesi'ne kadar ormanların genelini koruma amacı taşıyan herhangi bir düzenleme yapılmamıştır. Cumhuriyet Dönemi de dahil 1937 yılında çıkarılan 3116 Sayılı Orman Kanunu'na kadar yürürlükte kalan bu nizamname ormanlardan yararlanmaya ilişkin bazı düzenlemeler yapmış, ancak ormanların genişletilmesine dönük bir içeriğe sahip olmamıştır. Nizamname orman işletmeciliği açısından yüklenici (müteahhit) işletmeciliğini (iltizam ormancılığı) benimsemiştir (Gülen ve Özdönmez, 1981).

1937 yılından itibaren kurulmaya başlayan devlet orman işletmeleri ve ormancılıkta devlet işletmeciliği ulusal ormancılık politikası açısından günümüze kadar süren temel taş olma özelliğini kazanmıştır. 3116 Sayılı Kanun ormanlardan parasız yararlanmayı kaldırmış devlet orman işletmeleri ormanları eskisine göre çok daha güçlü şekilde korumaya başlamıştır (Gümüş, 2018). Bu durum ormanlardan geleneksel olarak, gelişigüzel ve parasız yararlanma alışkanlığı olan kırsal toplulukların tepkisine yol açmıştır. Yüzyıllara dayanan kırsal yoksulluk ve yoksunluk ile ormanları korumaya yönelik önlemler birbiriyle çelişince orman-halk ilişkilerinde gerilimler yaşanmıştır (Toksoy vd., 2005; Akesen ve Ekizoğlu, 2010). 1946 y1lında başlayan çok partili dönemde siyasal partiler orman-halk ilişkilerindeki bu gerilimi azaltmak yerine kullanmayı tercih etmiş, ormanlar ve ormancılık siyasi propaganda aracına dönüşmüştür. Artan orman suçları ve sık sık çıkarılan af yasaları orman-halk ilişkilerini içinden çıkılmaz bir sarmala dönüştürmüş, 1960 yılında askeri bir darbe ile yönetime el koyan Milli Birlik Hükümeti, hazırladığı yeni Anayasa aracılığıyla bu sarmalı kıracak önlemler alma arayışına girmiştir. 1961 Anayasası'nın 131. maddesi bu koşullar altında şekillenmiştir. Fakat yeniden oluşan parlamenter sistem; eski alışkanlıklarına çok çabuk dönmüş ve özellikle orman köylüsünün sorunlarını çözecek rasyonel önlemleri hayata geçirmek yerine köylüye ormandan tarla, bağ, bahçe vermenin, işlenen orman suçlarını affetmenin yollarını aramıştır. Bu arayışın sonucu olarak Anayasa'nın 131. maddesi 1970 yılında TBMM'de grubu bulunan bütün partilerin mutabakatı ile çıkarılan 1255 sayılı yasa ile değiştirilmiştir.

1255 sayılı yasa, aslında Türkiye'nin ulusal ormancılık politikasının halen geçerli olan ana bakış açısını yansıtması açısından anlamlıdır. Bu bakış açısı, insan-orman ikileminde daima insanı önde tutan ve bu yönüyle insancıl ve halkçı bir niteliğe sahipmiş gibi görünen, ancak ormanlara verdiği zararlar nedeniyle insan da dahil bütün ekosisteme geri dönülmez zararlar getiren bir yaklaşımdır. Diğer bir ifadeyle söz konusu yaklaşım ile ormanların siyasi bir rant aracı görüldüğü ve kullanıldığı belirtilebilir.

Bu makalede önce 1961 Anayasası'nın 131. maddenin nasıl oluştuğu aktarılmıştır. Daha sonra 1255 sayılı yasa çıkana kadar gerçekleşen olaylara değinilmiştir. Ardından 1255 sayılı yasanın çıkışı sırasında TBMM'de (Millet Meclisinde ve Cumhuriyet Senatosundan) yapılan görüşmeler detaylıca irdelenmiş, konuyla ilgili bilim ve meslek camialarının yaklaşımları gözden geçirilmiştir. Son olarak 1255 sayılı yasanın Türkiye ulusal ormancılık politikası açısından taşıdığı anlam ve bugüne dek uzanan etkileri ortaya konulmuştur.

\section{Materyal ve Metot}

Çalışmada literatür araştırması ve arşiv taraması olmak üzere iki temel veri kaynağı kullanılmıştır. Elde edilen veriler doküman analizi yönteminden yararlanılarak değerlendirilmiştir. Doküman analizi, araştırılan konuya ilişkin verilere ulaşmak amacıyla ilgili basılı ve elektronik belgelerin bilimsel esaslar çerçevesinde, sistematik olarak incelenmesini kapsayan nitel bir araştırma yöntemidir (Çepni, 2018; Kıral, 2020). Yöntem kapsamında öncelikle belgelere ulaşma aşaması tamamlanmış, ardından orijinallikleri değerlendirilmiş, belgelerin içeriği ve kapsamı tam olarak anlaşılmış, incelenen belgelerdeki veri ve bilgiler analiz edilmiş, yorumlanmış ve raporlanmıştır (Yıldırım \& Şimşek, 2013). 
Literatür araştırması özellikle 1950-1980 arası yayınlara yönelik olarak yapılmıştır. 1255 sayılı yasal düzenleme öncesi ve sonrasında yapılan yayınlar aracilığıyla hem dönemin ormanlarla ilgili gelişmeleri ortaya konulmaya çalışıllmış hem de 1255 sayılı yasaya ilişkin değerlendirmeler elde edilmiștir. Özellikle İstanbul Üniversitesi Orman Fakültesi Dergisi, Türkiye Ormancılar Derneği tarafından yayımlanan Orman ve Av Dergisi ile TMMOB Orman Mühendisleri Odası tarafından yayımlanan Orman Mühendisliği Dergisinin 1950-1980 arası bütün sayıları incelenerek, ilgili yayınlar literatür araştırmasına dahil edilmiştir.

Arşiv taraması ise Türkiye Büyük Millet Meclisi (TBMM) Kütüphane ve Arşiv Hizmetleri Daire Başkanlığının dijital olarak kullanıma sunduğu Cumhuriyet Dönemi Meclisleri Genel Kurul Tutanaklarına Erişim Sistemi (https://www.tbmm.gov.tr/kutuphane/tutanak_sorgu.html) üzerinden yapılmıştır. Bu sistem üzerinden 1255 sayılı yasanın Millet Meclisi ve Cumhuriyet Senatosu'ndaki görüşmelerinin tutanaklarının yayımlandığı Millet Meclisi Tutanak Dergisi ve Cumhuriyet Senatosu Tutanak Dergisi’nin ilgili sayılarına ulaşılmıştır. İncelenen dergiler şunlardır:

- Millet Meclisi Tutanak Dergisi

o Dönem 3, Cilt 4, Toplant1 1, 68'nci Birleşim, 13.4.1970 Pazartesi

o Dönem 3, Cilt 4, Toplantı 1, 69’uncu Birleşim, 13.4.1970 Salı

- Cumhuriyet Senatosu Tutanak Dergisi

o Cilt 57, Toplant 9, 60' incı Birleşim, 16.4.1970 Perşembe

o Cilt 57, Toplant1 9, 61'inci Birleşim, 17.4.1970 Cuma

\section{Bulgular}

Bulgular bölümünde 1961 Anayasası öncesinde ormanlar ve ormancılıkla ilgili gelişmeler, anayasaya ormancılıkla ilgili hükümlerin girişi, yeni anayasa sonrası gelişmeler ve anayasanın 131. maddesinin değiş̧tirilmesi ile ilgili gelişmeler anlatılmış ardından TBMM'ndeki görüşmeler ile Orman Mühendisleri Odası ve İ.Ü. Orman Fakültesinin konuya ilişkin görüşleri değerlendirilmiştir.

\subsection{Anayasası Öncesi Ormanlar ve Ormancılıkla İlgili Gelişmeler}

Ulusal Kurtuluş Savaşı'nda elde edilen askeri zaferin ardından kurulan Türkiye Cumhuriyeti'ne Osmanlı Devleti'nden ormancılık alanında da sağlıklı bir miras kalmamıştır. 1839 yılında başlayan ormancılıkta örgütlenme çalışmaları, 1857 yılında kurulan ve bugünkü İstanbul Üniversitesi-Cerrahpaşa Orman Fakültesinin temeli olan orman okulu, 1870 yılında yürürlüğe konan Orman Nizamnamesi gibi adımlar elbette önemli atılımlardır. Ancak Cumhuriyet kurulduğu yıllarda ülke ormanları korunamamakta, işletilmesi için yüklenicilere teslim edilmiş olan ormanlar her geçen gün azalmaktadır. TBMM tarafindan henüz Cumhuriyet kurulmadan Baltalık Yasası (1920), Cumhuriyet'in kurulmasını takiben 484 Sayılı Devlet Ormanlarından Köylülerin Yararlanma Yasası (1924) ve 504 Sayılı Türkiye'de Ormanların Bilimsel Yöntemlerle Yönetilmesi ve İșletilmesi Yasası (1924) çıkarılmıș, Orman Yüksek Meclisi (1924) kurulmuştur. Bunlara ek olarak ormanlar ve ormancılıkla doğrudan ya da dolaylı ilişsisi bulunan adımlar da atılmıştır. 442 Sayılı Köy Kanunu'nun çıkarılması, aşarın kaldırılması, çiftçiyi topraklandırma hareketleri ve Köy Enstitülerinin kurulması bu adımlar arasındadır (Erdönmez, 1994). Cumhuriyet'in ilk yıllarında ormanlar ve ormancılık konusunun ülke yönetiminde öncelikli olarak ele alınan alanlardan biri olduğu söylenebilse de 1937 yılına kadar ormancılıkta köklü bir dönüşümün yaşandığını söylemek olanaklı değildir.

Türkiye'de bilimsel ve teknik anlamda ormancılık 1937 yılında çıarılan 3116 Sayılı Orman Kanunu ile başlamıştır (Özdönmez vd., 1996; Erdönmez vd., 2010). 1937 yılı Türkiye ormancılığı için bir dönüm noktası olmuştur, çünkü o tarihe kadar ormanlar devamlılık ilkesi dikkate alınmadan yönetilmiştir. Orman Yasası ile öncelikle ormanların etkin bir şekilde korunması amaçlanmış, orman mülkiyetinin devlet elinde toplanması ve devlet orman işletmeciliği esas alınmıştır (Gümüş, 2018). 3116 Sayılı Orman Yasası ormancılığa temel olarak iki görev vermiştir; bunlardan birincisi var olan ormanları korumak, ikincisi ise yeniden orman yetiştirerek orman varlığını artırmaktır (Diker, 1947). Aynı yıl çıkarılan 3204 Sayılı Kanun ile tüzel kişiliği bulunan ve katma bütçeli Orman Genel Müdürlüğü kurulmuş, yine aynı yıl ilk devlet orman işletmesi Karabük’te açılmıştır. Ne var ki, kısa süre sonra başlayan II. Dünya Savaşı, savaşın tarafı olmasa da Türkiye'yi olumsuz etkilemiş ve Orman Yasası'nın çıkarılması ve devlet orman işletmelerinin kurulmasıyla amaçlanan hedeflere ulaşılması güçleşmiştir. Gerçekten de yapılan bir araştırmaya göre yalnızca Antalya'da 1926-1946 arasını kapsayan 20 yıllık dönemde her yıl 3 bin 700 ha orman azalması meydana gelmiştir. Antalya'da görülen bu azalma oransal olarak bütün ülke ormanlarına yayıldığında, yurt çapında ve belirtilen dönemde her yıl 100 bin hektarlık ormansızlaşmanın meydana geldiği anlaşılmaktadır (Diker ve Savaş, 1947). 
II. Dünya Savaşı sonrası, Türkiye'de rejim açısından önemli değişiklikleri beraberinde getirmiştir. 1946 yılında çok partili hayata geçilmesi ve 1950 yılındaki seçimlerde iktidarın el değiştirmesiyle başlayan dönem, çevrenin merkezin elinde tuttuğu siyasal iktidara ortak olmaya başlaması süreci olarak değerlendirilebilir (Akıncı ve Usta, 2015). Türkiye’de 1933-1950 döneminde devlet öncülüğünde kalkınma modeli uygulanmış ve İkinci Dünya Savaşı'na rağmen çok önemli bir kalkınma hamlesi gerçekleşmiş (Koçtürk ve Gölalan, 2010), 1950-1960 arası ise devletçi ekonomiden liberal ekonomi politikalarına geçişe sahne olmuştur (Kanca, 2012). 1950 yılında Demokrat Parti iktidarıyla birlikte traktör dışalımına koşut olarak tarımda hızlı bir gelişme süreci yaşanmış, ancak toprak reformu yapılmamış ve altyapısı yetersiz olan ülkede tarım sektörü tıkanarak kente doğru göç süreci başlamıştır (Öztürk, 2008).

Hem siyasal hem de ekonomik alanda yaşanan bu değişimler ormanlar ve ormancıllı̆̆ da etkilemiştir. Özellikle orman köylerinde çok daha şiddetli olarak hissedilen kırsal yoksulluk halkın ormana yönelik taleplerini artırmış, ormanı koruma ile halkın ormandan yararlanma isteklerinin çatışması sonucunda orman-halk ilişkileri son derece olumsuz bir duruma gelmiştir. 1950’lere doğru orman köylüsünün sıkıntılarını azaltmak için bazı girişimlerde bulunulsa da (Bingöl, 1990), bu girişimler olumlu sonuç vermemiş, orman konusu siyasi çıar gibi amaçlar için kullanılmaya başlanmıştır (İnal, 1971). 1950 yılında art arda yapılan iki yasal düzenleme ile orman-halk ilişkilerindeki gerilim azaltılmaya çalışılmıştır. 3116 Sayılı Orman Yasası'nı değiştiren 5653 Sayılı Yasa ile muhafaza niteliği taşımayan ve devamlı orman hasılatı vermeyen makilikler orman tanımı dışarısına çıkarılarak orman köylüsüne yeni tarım alanları kazandırılmaya çalışılmış; yine 3116 Sayılı Orman Yasası'nı değiştiren 5658 Sayılı Yasa ise 1945 yılında çıkarılan 4785 Sayılı Yasa ile devletleştirilen köy ve belediyelere ait ormanlarla özel ormanların sahiplerine geri verilmesini olanaklı kılmıştır (Erdönmez, 2020).

1956 yılında çıkarılan 6831 Sayılı Orman Yasası ile 3116 Sayılı Orman Yasası bütünüyle yürürlükten kaldırılmışıır. 6831 Sayılı Orman Yasası orman köylüsünün sorunlarının çözümü açısından yepyeni bir adım atmıştır. Gümüş (2018)'e göre çıkarılan bu yeni yasa ormancılık politikası açısından köklü değişiklikler yapmamış, fakat ormancılık sorunlarının temelde bir iskân sorunu olarak görülmesinden dolayı orman köylülerinin bulundukları yerlerden başka yerlere yerleştirilmesi amacına yönelmiştir. Gerçekten de 6831 Sayılı Orman Yasası'nın 2. maddesi ile su ve toprak rejimine zarar vermeyen orman alanlarının (düz ya da düşük eğimli alanlardaki orman alanları) orman rejimi dışarısına çıkarılması; 13. maddesi ile de bulundukları yerde kalkındırılmaları olanaklı görülmeyen orman köylerinin bu alanlara taşınması hükmü getirilmiştir. Bu hükümler doğrultusunda 1958-1960 yılları arasında, 6831 Sayılı Orman Yasası'nın 2. ve 13. maddelerine dayanılarak çıkarılan Bakanlar Kurulu Kararları ile yaklaşık 200 bin ha orman alanı orman sınırları dışarısına çıkarılmış, bu alanlar bulundukları yerde kalkındırılmaları olanaklı olmayan orman köylerinin kullanımına tahsis edilmiş; fakat söz konusu orman köyleri tahsis edilen söz konusu alanları kullanmaya başladıkları halde eski köylerini de terk etmemiştir. Bu nedenle yapılan düzenleme büyük orman tahriplerine yol açmış ve 1960 yılında göreve gelen Milli Birlik Hükümeti 28.9.1960 tarihinde çıkardığı 5/389 Sayılı Karar ile yukarıda belirtilen bakanlar kurulu kararlarını iptal etmiş̧ir (Gümüş, 2018).

Halkın sorunlarının temeline inmeyen ve sorunları çözmekten çok siyasi çıkar sağlamayı amaçlayan bu girişimler doğal olarak olumlu sonuçlar ortaya çıkarmamış, ormanlardan tarla açmak, kaçak ağaç kesmek; ormanda yasa dışı hayvan otlatmak gibi orman suçlarının sayısı hızla artmıştır. Ülke genelinde işlenen ve kayıtlara geçen toplam orman suçu sayısı 1937 yılında 5 bin 351 iken 1960 yılında 108 bin 744'e (Özdönmez, 1965), her 100 bin kişi başına işlenen orman suçu sayısı ise 1951'de 238 iken 1960'ta 392'ye (Özdönmez, 1973a) yükselmiştir. 1955-1960 yılları arasındaki altı yıllık dönemde, çıkarılan yangınlar da dahil işlenen orman suçlarının yalnızca odun hammaddesi olarak yarattığı zararın parasal karşılığı, söz konusu dönemin fiyatlarıyla 30 milyon liranın üzerindedir (Özdönmez, 1965). Alınan önlemler nedenlere değil sonuçlara dönük olduğundan orman suçları azalmayınca, siyaset bu kez çözümü orman suçlarına yönelik af kanunları çıkarmakta bulmuştur. 1950, 1954, 1956 ve 1958 yıllarında orman suçlarına yönelik olarak dört farklı af düzenlemesi yapılmış olmasına karşın yayımlanan resmi adalet istatistiklerine göre 1960 yılında Türk Ceza Kanunu ve özel kanunlara göre hüküm giyenlerin \%31'ini özel kanunlara göre hüküm giyenler, \%62'sini de tek başına orman suçundan mahkûm olanlar oluşturmuştur (İnal, 1971).

\subsection{Anayasası'na Ormancılıkla İlgili Hükümlerin Girişi}

1950'li yıllar sosyal ve ekonomik açıdan olduğu kadar siyasal açıdan da son derece çalkantılı geçmiştir. 1923 yılında kurulan Cumhuriyet ve 1946 yılında başlayan çok partili rejimle şekillendirilmeye çalışılan demokratikleşme süreci 1960 yılında büyük bir hasar almıştır. Mevcut hükümet 27 Mayıs 1960'ta Türk Silahlı Kuvvetlerinden 38 subayın kurduğu ihtilal komitesi tarafından bir darbeyle devrilmiş ve TBMM feshedilmiştir (Emiroğlu, 2011). En yaşlısı 65 en genci 27 yaşında, 32'si kurmay olan ihtilal komitesi müdahalenin planlayıcısı ve uygulayıcısı olarak Milli Birlik Komitesi adını almış, yeni bir anayasa yürürlüğe girene kadar hukuk 
profesörlerine 27 maddelik bir geçici anayasa hazırlatılmış ve seçimle yeniden bir parlamento oluşana kadar 1921 Anayasası'nın parlamentoya verdiği bütün yetkiler Milli Birlik Komitesine (MBK) verilmiştir (Börklüoğlu, 2017). Böylelikle oluşan hükümet de Milli Birlik Hükümeti (MBH) olarak adlandırılmıştır.

MBK, yeni bir anayasa hazırlamak üzere çalışmalara başlamış ve hazırlanacak yeni anayasanın tasarısını ortaya koymak amaciyla 27 Mayıs 1960 tarihinde bir Anayasa Komisyonu kurmuştur. Anayasa Komisyonu tarafından hazırlanan anayasa tasarısına ormancılıkla ilgili hükümlerin girmesine ilişkin gelişmeler aşağıda kısaca ve maddeler halinde aktarılmıştır (İnal, 1971):

- Anayasa Komisyonu toplumun anayasa hakkındaki düşüncelerini ve ihtiyaçlarını ortaya koyabilmek amacıyla bir anket hazırlamıştır. Bu anketin 29'uncu sorusu şu şekildedir: “Amme emlâkinin, diğer milli servetlerin ve hususiyetle ormanların korunması hakkında anayasaya hükümler konulmasını düşünüyor musunuz?”

- Bu sorunun çeşitli kurum, kuruluş ve kişiler tarafından ayrı ayrı yanıtlandırılması yerine, 15 Haziran 1960 tarihinde Tarım Bakanlığından bürokratlar, orman fakültesi öğretim üyeleri ile meslek örgütleri ve sivil toplum kuruluşları temsilcilerinin katıldığı bir toplantı düzenlenmiş ve anketteki 29'uncu soru değerlendirilmişstir.

- Toplanan katılımcılar 17 Haziran 1960 tarihinde iki alt komisyon kurmuşlardır. Bunlardan birincisinin görevi anayasaya girmesi önerilecek hükümleri saptamak, ikincisinin görevi ise bu hükümleri düzenleyip gerekçelendirmektir.

- 18 Haziran 1960 tarihinde alt komisyonlarca dört madde şeklinde hazırlanan hükümler, toplantı katılımcılarının tamamının oyu ile kabul edilmiş ve hükümler 19 Haziran 1960 tarihinde bir üst yazı ile Orman Genel Müdürlüğüne sunulmuştur. Orman Genel Müdürlüğü hazırlanan hükümleri İstanbul'da çalışan Anayasa Komisyonuna göndermiştir.

- Anayasa Komisyonu kendilerine yazıyla iletilen hükümler hakkında daha detaylı bilgi almak için, Ankara'daki toplantıda sözcü olarak görevlendirilen Prof. Dr. Fehim Firat ve Prof. Dr. Selahattin İnal'1 toplantıya davet etmiş ve onlardan sözlü bilgi almıştır.

- Bütün maddeler hakkındaki çalışmalarını tamamlayan Anayasa Komisyonu, 15 Ekim 1960 tarihinde hazırladığı “İkinci Cumhuriyet Anayasası Ön Projesi”ni MBK’ye sunmuştur. Bu metnin 29'uncu maddesinde ormanların kamulaştırılması konusunu ele almış, 38. madde toprak dağıtımının hiçbir zaman ormanların küçülmesi sonucunu doğuramayacağı hükmünü içermiştir. Ormancı bilim adamı ve uzmanların önerdiği hükümlerin büyük bir bölümü ise 159. maddede toplanmıştır.

- MBK 13.12.1960 tarih ve 157 ve 158 Sayılı Kanunlarla Kurucu Meclis ve bu meclisin bir bölümü olarak Temsilciler Meclisini kurmuş; Temsilciler Meclisi de 9.1.1961 tarihinde Temsilciler Meclisi Anayasa Komisyonunu (TMAK) kurmuştur.

- TMAK yaklaşık iki aylık çalışma ile Anayasa Komisyonu tarafından oluşturulan İkinci Cumhuriyet Anayasası Ön Projesinde bazı değişiklikler yaparak hazırladığı anayasa tasarısını Temsilciler Meclisi Başkanlığına sunmuştur.

- TMAK tarafindan hazırlanan tasarı Kurucu Meclis, Temsilciler Meclisi ve MBK tarafinda müzakere edilmiş ve 9.7.1961 tarihinde halkoyuna sunulmak yoluyla kabul edilerek 20.7.1961 tarihinde yürürlüğe girmiştir.

Yeni Anayasa'da ormancılıkla ilgili hükümler 37, 38 ve 131. maddeler olarak yer almıştır. Bunlardan 37 ve 38. maddelerin ormancılıkla ilgili kısımları ile 131. maddenin tamamının yürürlüğe giren özgün halleri aşağıdaki gibidir:

\section{Toprak Mülkiyeti}

Madde 37.- ... Toprak dağıtımı, ormanların küçülmesi veya diğer toprak servetlerinin azalması sonucunu doğuramaz.

\section{Kamulaştırma}

Madde 38.- ... Çiftçinin topraklandırılması, ormanların devletleştirilmesi, yeni orman yetiştirilmesi ve iskân projelerinin gerçekleştirilmesi amaçlarılla kamulaştırılan toprak bedellerinin ödeme şekli kanunla gösterilir...

Ormanların korunması ve geliştirilmesi

Madde 131.- Devlet, ormanların korunması ve ormanlık sahaların genişletilmesi için gerekli kanunları koyar ve tedbirleri alır. Bütün ormanların gözetimi Devlete aittir. 
Devlet ormanları, kanuna göre Devleţ̧e yönetilir ve işletilir. Devlet ormanlarının mülkiyeti, yönetimi ve işletilmesi özel kişilere devrolunamaz. Bu ormanlar, zamanaşımıyla mülk edinilemez ve kamu yaran dişında irtifak hakkina konu olamaz.

Ormanlara zarar verebilecek hiçbir faaliyet ve eyleme müsaade edilemez.

Ormanlar içinde veya hemen yakınında oturan halkın kalkındırlması ve ormanı koruma bakımından gerekirse başka yere yerleştirilmesi kanunla düzenlenir.

Yanan ormanların yerinde yeni orman yetiştirilir ve bu yerlerde başka çeşit tarım ve hayvancılık yapılamaz.

Orman suçlan için genel af çıkarılamaz; ormanların tahribine yol açacak hiçbir siyasi propaganda yapılamaz.

\subsection{Yeni anayasa sonrası gelişmeler}

Anayasa'nın yürürlüğe girmesinden yaklaşık üç ay sonra, 15 Ekim 1961 tarihinde genel seçimler yapılarak yeniden parlamenter sisteme dönülmüştür. Ne var ki, siyasal çalkantılar uzun süre devam etmiş, 20 Kasım 1961 tarihinde kurulan İsmet İnönü Hükümetinden itibaren 12 Eylül 1980 tarihinde gerçekleştirilen bir diğer askeri darbeye kadar geçen 19 yıllık süreçte tam 18 farklı hükümet kurulmuştur (26.- 43. hükümetler). Buna karşıllk, Anayasa'nın ormanları güçlü bir şekilde koruma altına alan hükümleri siyasi partilerde hoşnutsuzluklar yaratmış ve pek çok konuda birbiriyle anlaşamayan siyasetçiler bu konuda girdikleri arayışlarda rahatlıkla ortak uzlaşı noktası bulabilmişlerdir.

Oluşan hoşnutsuzluğun ilk somut ürünü Orman Genel Müdürlüğü tarafından 1963 yılının sonlarına doğru hazırlanarak başbakanlığa, oradan da TBMM Başkanlığına gönderilen 663 Sayılı Kanun Tasarısı Taslağıdır (İnal, 1971). Tasarının yasalaşma süreci oldukça uzun sürmüş ve 14.10.1961 tarihinden önce orman niteliğini kaybederek daha verimli kültür arazisine dönmesi uygun olan yerlerin orman sınırları dışarısına çıkarılmasını içeren geçici 6. maddenin 6831 Sayılı Orman Yasası'na eklenmesini öngören yasa 15.7.1965 tarihinde kabul edilip 24.7.1965 tarihli Resmi Gezete'de yayımlanarak yürürlüğe girmiştir. Ayrıca yasanın uygulanmasını düzenlemek amacıyla bir de yönetmelik yayımlanmıştır. ${ }^{1}$ Bu uzun süreçte tasarı özellikle orman mühendisliği meslek camiasından yoğun eleştiri almıştır. Orman Mühendisleri Odası İdare Heyeti (Yönetim Kurulu) ormanhalk ilişkilerini ele aldığı bildirisinde orman köylülerinin kalkındırılması ve orman-halk ilişkilerinin düzenlenmesi sorununu orman idaresi ile vatandaşlar arasındaki tarla ihtilaflarının çözümü konusunda toplamanın yanlışlı̆̆ına vurgu yapmıştır (Anonim, 1964). Yine Orman Mühendisleri Odası söz konusu yasanın TBMM'de kabul edilmesinin ardından Cumhurbaşkanı'na bir mektup göndererek, yapılan yasal düzenlemenin Anayasa'nın 37. ve 131. maddelerine ve ormanların bütünlüğü ilkesine aykırı olduğunu vurgulamış, Cumhurbaşkanı'nın yasayı TBMM'ye iade etmesini ya da Anayasa Mahkemesine sevk etmesini talep etmiştir (Anonim, 1965a). Benzer şekilde Orman Mühendisleri Odası adına Yüksek Orman Mühendisi-Avukat M. Nedim Tunçsiper TBMM geçici encümeninde 21.12.1964 tarihinde yaptığı konuşmasında bu düzenlemenin Anayasa'ya aykırı olduğunu dile getirmiştir (Anonim, 1965b). Orman mühendisliği meslek camiası adına Orman Mühendisleri Odası tarafından yapılan uyarıların benzerleri, yapılmak istenen düzenlemenin sorunu çözemeyeceği ve Anayasa'ya aykırı olduğu gerekçeleriyle bazı uzman orman mühendisleri tarafından da ayrıca dile getirilmiş (Abbasoğlu, 1965; Sertbaş, 1965), ancak yasanın yürürlüğe girmesi engellenememiştir.

Çatalzeytin Sulh Hukuk Mahkemesi görmekte olduğu bir orman davası dosyasının incelenmesi sırasında oluşturduğu kanaate dayanarak, 6831 Sayılı Orman Yasası'na 663 Sayılı Yasa ile eklenen geçici 6. maddenin Anayasa'nın 37. ve 131. maddelerine aykırı olduğu iddiasıyla Anayasa Mahkemesine başvuruda bulunmuştur. Anayasa Mahkemesi 10.3.1966 tarihinde ${ }^{2}$ aldığı kararla belirtilen geçici maddenin Anayasa'nın 37. ve 131. maddelerine aykırılığı nedeniyle iptaline 7'ye karşı 8 oyla karar vermiştir.

Anayasa Mahkemesinin kararından sonra siyasi arayışlar devam etmiştir. Tarım Bakanlı̆̆ı 1967 yılında üç farklı yasa taslağını görüş almak üzere ilgili kurum ve kuruluşlara göndermiştir. Bu taslaklardan biri Orman Yasası'nın orman tanımını içeren 1. maddesinin değiştirilmesine ilişkindir. Bu değişiklikle orman sayılmayan alanlara "Orman içindeki dağınık evler ve her çeşit yapı ve tesisler hariç olmak üzere 15.10.1961 tarihinden önce şehir, kasaba ve köy iskân topluluğu içinde kalan yerler" de eklenmek istenmiştir. Daha önceki girişimde olduğu gibi bu girişim de özellikle meslek camiasından büyük eleştiri almıştır. Nitekim Türkiye Ormancılar Cemiyeti (Derneği) ve Orman Mühendisleri Odası ortak bir bildiri hazırlayarak, bu değişikliğin orman sahasını rezerv

${ }^{1} 663$ Sayılı Kanunla 6831 Sayılı Kanuna Eklenen Geçici 6’ncı Maddenin Uygulanmasına Dair Yönetmelik. Resmi Gazete: 21.2.1966 tarih ve 12232 say1.

${ }^{2}$ Esas No: 1965/44, Karar No: 1966/14, Karar Tarihi: 10.3.1966, Resmi Gazete: 4.6.1966 tarih ve 12314 say1. 
ziraat arazisi olarak değerlendiren bir görüşün ürünü olduğunu, bu tehlikeli çalışmaları asla tasvip etmediklerini beyan etmişlerdir (Anonim, 1967). Bu tepkiler üzerine taslak bakanlıkça geri çekilmiş ve üzerinde çalışılmaya devam edilmiştir. Orman Genel Müdürlüğü taşra teşkilatından 27 görevliyi Ankara’ya çağırmış, merkezden 7 görevlinin katılımıyla 34 kişilik bir komisyon kurulmuş; toplantılar sırasında başkanlık eden Orman Genel Müdür Vekilinin zorlayıcı tavrı tepki almış, görüşülen taslak 11'e karşı 21 oyla reddedilmiştir. Buna rağmen bakanlık taslakta bazı değişiklikler yaparak TBMM’ye sunulacak hale getirmiştir (İnal, 1971). Konunun önemine binaen İstanbul Üniversitesi Orman Fakültesi Profesörler Kurulu bir ön rapor hazırlanması amacıyla Ormancılık Politikası Kürsüsünü görevlendirmiş; hazırlanan ön rapor 4.5.1967 tarihli Profesörler Kurulunda görüşülerek uygun bulunmuş ve kamuoyuna duyurulmuştur ${ }^{3}$. Kamuoyuna açıklanan bildiride, hazırlanan kanun tasarısı taslağının yaptığı yeni orman tanımının ülke ormanlarını azaltacağı, Anayasa ve kamu yararına aykırı olduğu; devlet mülkiyetine geçmiş ormanların özel kişilere devrinin ormanları azaltacağı ve Anayasa'ya aykırı olduğu; halk-orman ilişkilerinin ormanları daraltarak değil istikrarlı bir ormancılık politikası ile mümkün olacağı vurgulanmıştır. Hazırlanan kanun tasarısı taslağına itirazlar yalnızca ormancılardan gelmemiştir. Türkiye Ziraat Odaları Birliği, Ziraat Mühendisleri Odası ve Ankara Üniversitesi Ziraat Fakültesi Profesörler Kurulu da hazırlanan taslağa ilişkin eleştirilerini kamuoyuna duyurmuşlardır (İnal, 1971). Oluşan tepkilerin büyüklüğü nedeniyle Tarım Bakanlığı taslağı TBMM'ye göndermekten vazgeçmek zorunda kalmıştır.

Tarım Bakanlığı 1968 yılının sonlarına doğru 1967 yılında hazırlanan taslağa bazı ekleme ve çıkarmalar yaparak yeni bir taslak hazırlamış ve bu kez ilgili kurum ve kuruluşların görüşüne başvurmadan TBMM'ye sevk etmiştir. TBMM'de süreç işlerken yine meslek ve sivil toplum kuruluşları ile İstanbul Üniversitesi Orman Fakültesi olumsuz tepki göstermiş, tasarı araya giren 1969 yılı seçimleri nedeniyle TBMM'de görüşülmeden kadük hale gelmiştir (İnal, 1971).

Açıkça görüldüğü gibi 1961 Anayasası'nda yer alan ormancılıkla ilgili hükümler hem 663 Sayılı Yasa ile 6831 Sayılı Orman Yasası'na eklenen geçici 6. maddenin Anayasa Mahkemesi tarafından iptal edilmesinde hem de daha sonraki yıllarda hazırlanan kanun tasarısı taslaklarının eleştirilmesinde çok önemli bir direnç ve dayanak noktası oluşturmuştur. Bu nedenle, siyasal partilerin Orman Yasası'nı değil Anayasa'daki ormancılıkla ilgili hükümleri değiştirme arayışlarının ortaya çıktığı yeni bir dönem başlamıştır.

\subsection{Anayasa'nın 131'nci maddesinin değiştirilmesi}

1961 Anayasası'nın ilgili maddelerine göre TBMM, Millet Meclisi ve Cumhuriyet Senatosu adlı iki organdan oluşmakta ve yasama işlevi bu iki organca yerine getirilmektedir. Millet Meclisi seçimle belirlenen 450 milletvekilinden oluşmakta, Cumhuriyet Senatosu ise seçimle belirlenen 150 üyeye ek olarak Cumhurbaşkanınca saptanan 15 üyeden oluşmaktadır. Ayrıca, 13 Aralık 1960 tarihli ve 157 sayılı Kanun'un altında adları bulunan MBK Başkanı ve üyeleri ile eski Cumhurbaşkanları, yaş kaydı gözetilmeksizin, Cumhuriyet Senatosunun doğal üyesidirler.

12 Ekim 1969 tarihinde yapılan genel seçimlerden sonra TBMM’de öncelikli olarak ele alınan konulardan biri de Anayasa'nın 131. maddesinin değiştirilmesi olmuştur. Bu konuda 1969 yılı kasım ayında TBMM Başkanlığına iki farklı kanun teklifi sunulmuştur. Bunlardan biri 346 TBMM üyesi tarafından diğeri de 225 TBMM üyesi tarafından imzalanmıştır. Millet Meclisi Anayasa Komisyonu her iki teklifi de inceleyerek, tekliflerin birbiriyle bütünüyle aynı nitelikte olması kanaatine ulaşmış ve bu teklifleri tek bir teklif gibi değerlendirmiş; tekliflerde bazı değişiklikler yaparak hazırladığı raporu 11.4.1970 tarihinde TBMM Başkanlığına sunmuştur. Sunulan bu raporda Anayasa'nın 131. maddesinin değiştirilmesi önerilen hali ile 1961 Anayasası'ndaki özgün halinin karşılaştırması Tablo 1'de gösterilmiştir.

Görüldüğü gibi toplam altı fikradan meydana gelen 131. maddenin 4. 5. ve 6. fikralarının değiştirilmesi önerilmekte; 4. ve 5. fikralara ek hükümler konulurken 6. fikradaki orman suçlarına ilişkin genel af çıkarılamayacağı hükmü kaldırılmaktadır. Ayrıca Anayasa'nın özgün halinde 131. maddenin başlığı “Ormanların korunması ve geliştirilmesi” şeklindeyken, teklif bu başlığın "Ormanların ve orman köylüsünün korunması, ormanların geliştirilmesi” şekline getirilmesini içermektedir.

\subsection{TBMM'de yapılan görüşmeler}

Daha önce de belirtildiği gibi 1961 Anayasası'na göre TBMM, Millet Meclisi ve Cumhuriyet Senatosu adlı iki farklı organdan oluşmaktadır. Kanun teklifleri önce Millet Meclisinde daha sonra da Cumhuriyet Senatosunda görüşülmekte ve her iki organ tarafından kabul edilen teklifler yasalaşmaktadır. Ayrıca yine 1961 Anayasası'nın

\footnotetext{
${ }^{3}$ Söz konusu bildiri 6.5.1967 tarihli Cumhuriyet Gazetesi’nde yayımlanmıştır.
} 
155. maddesine göre Anayasa'nın değiştirilmesine ilişkin teklifler ivedilikle görüşülememektedir. Buna karşın, yukarıda açıklanan Anayasa'nın 131. maddesinin değiştirilmesine ilişkin teklif Anayasa Komisyonundan TBMM Başkanlığına sevk edilirken sunulan raporda, teklifin kamuoyunun çok yakından ilgilendiği bir konu olması göz önünde bulundurularak diğer işlerden önce görüşülmesinin sağlanması istenmiştir. Bu isteğe uygun olarak teklif, 13-14 Nisan 1970 tarihlerinde Millet Meclisinde, 16-17 Nisan 1970 tarihlerinde de Cumhuriyet Senatosunda görüşülerek kabul edilmiştir.

Tablo 1. 1961 Anayasası'nın 131. maddesinin değiştirilmesine ilişkin teklifin TBMM Anayasa Komisyonundan çıkan hali ile özgün halinin karşılaştırması.

\begin{tabular}{|c|c|c|c|}
\hline Fikra & Özgün hali & Değiştirilmesi önerilen hali & Açıklama \\
\hline 1 & $\begin{array}{l}\text { Devlet, ormanların korunmasl ve } \\
\text { ormanlık sahaların genişletilmesi } \\
\text { için gerekli kanunları koyar ve } \\
\text { tedbirleri alır. Bütün ormanların } \\
\text { gözetimi Devlete aittir. }\end{array}$ & $\begin{array}{l}\text { Devlet, ormanların korunması ve } \\
\text { ormanlık sahaların genişletilmesi } \\
\text { için gerekli kanunları koyar ve } \\
\text { tedbirleri alır. Bütün ormanların } \\
\text { gözetimi Devlete aittir. }\end{array}$ & $\begin{array}{l}\text { Herhangi bir değişiklik } \\
\text { yok }\end{array}$ \\
\hline 2 & $\begin{array}{l}\text { Devlet ormanları, kanuna göre } \\
\text { Devletçe yönetilir ve işletilir. Devlet } \\
\text { ormanlarının mülkiyeti, yönetimi ve } \\
\text { işletilmesi özel kişilere } \\
\text { devrolunamaz. Bu ormanlar, } \\
\text { zamanaşımıyla mülk edinilemez ve } \\
\text { kamu yaran dışında irtifak hakkına } \\
\text { konu olamaz. }\end{array}$ & $\begin{array}{l}\text { Devlet ormanları, kanuna göre } \\
\text { Devletçe yönetilir ve işletilir. Devlet } \\
\text { ormanlarının mülkiyeti, yönetimi ve } \\
\text { işletilmesi özel kişilere } \\
\text { devrolunamaz. Bu ormanlar, } \\
\text { zamanaşımıyla mülk edinilemez ve } \\
\text { kamu yararı dışında irtifak hakkına } \\
\text { konu olamaz. }\end{array}$ & $\begin{array}{l}\text { Herhangi bir değişiklik } \\
\text { yok }\end{array}$ \\
\hline 3 & $\begin{array}{l}\text { Ormanlara zarar verebilecek hiçbir } \\
\text { faaliyet ve eyleme müsaade } \\
\text { edilemez. }\end{array}$ & $\begin{array}{l}\text { Ormanlara zarar verebilecek hiçbir } \\
\text { faaliyet ve eyleme müsaade } \\
\text { edilemez. }\end{array}$ & $\begin{array}{l}\text { Herhangi bir değişiklik } \\
\text { yok }\end{array}$ \\
\hline 4 & $\begin{array}{l}\text { Ormanlar içinde veya hemen } \\
\text { yakınında oturan halkın } \\
\text { kalkındırılması ve ormanı koruma } \\
\text { bakımından gerekirse başka yere } \\
\text { yerleştirilmesi kanunla düzenlenir. }\end{array}$ & $\begin{array}{l}\text { Ormanlar içinde ve hemen } \\
\text { yakınında oturan halkın } \\
\text { kalkındırılması ve orman koruma } \\
\text { bakımından, ormanların } \\
\text { gözetilmesi ve işletilmesinde } \\
\text { Devletle bu halkın işbirliği } \\
\text { yapmasını sağlayıcı tedbirler ve } \\
\text { gereken hallerde başka yerlere } \\
\text { yerleştirme kanunla düzenlenir. }\end{array}$ & $\begin{array}{l}\text { Ormanların gözetilmesi } \\
\text { ve işletilmesinde Devlet } \\
\text { ile orman köylüsünün } \\
\text { işbirliği yapmasını } \\
\text { sağlayıcı önlemlerin de } \\
\text { kanunla düzenleneceğine } \\
\text { ilişkin hüküm bu fıkraya } \\
\text { eklenmiştir. }\end{array}$ \\
\hline 5 & $\begin{array}{l}\text { Yanan ormanların yerinde yeni } \\
\text { orman yetiştirilir ve bu yerlerde } \\
\text { başka çeşit tarım ve hayvancılık } \\
\text { yapılamaz. }\end{array}$ & $\begin{array}{l}\text { Anayasanın yürürlüğe girdiği } \\
\text { tarihten önce bilim ve fen } \\
\text { bakımından orman niteliğini tam } \\
\text { olarak kaybetmiş olan tarla, bağ, } \\
\text { meyvalık, zeytinlik gibi çeşitli tarım } \\
\text { alanlarında veya hayvancılıkta } \\
\text { kullanılmasında yarar bulunan } \\
\text { topraklarla şehir, kasaba ve köy } \\
\text { yapılarının toplu olarak bulunduğu } \\
\text { yerler dışında orman sınırlarında } \\
\text { hiçbir daraltma yapılamaz. Yanan } \\
\text { ormanların yerinde yeni orman } \\
\text { yetiştirilir ve bu yerlerde başka çeşit } \\
\text { tarım ve hayvancılık yapıllamaz. }\end{array}$ & $\begin{array}{l}\text { Anayasa'nın yürürlüğe } \\
\text { girdiği tarihten önce } \\
\text { insan müdahalesi } \\
\text { sonucunda orman } \\
\text { niteliğini kaybederek } \\
\text { tarım ya da yerleşim } \\
\text { alanına dönüşmüş } \\
\text { alanların orman sınırları } \\
\text { dışarısına çıkarılmasına } \\
\text { olanak sağlayan hüküm } \\
\text { bu fıkraya eklenmiştir. }\end{array}$ \\
\hline 6 & $\begin{array}{l}\text { Orman suçlan için genel af } \\
\text { çıarılamaz; ormanların tahribine } \\
\text { yol açacak hiçbir siyasi propaganda } \\
\text { yapılamaz. }\end{array}$ & $\begin{array}{l}\text { Ormanların tahrip edilmesine yol } \\
\text { açan hiçbir siyasi propaganda } \\
\text { yapılamaz. }\end{array}$ & $\begin{array}{l}\text { Orman suçları için genel } \\
\text { af çıkarılamayacağına } \\
\text { ilişkin hüküm fıkradan } \\
\text { çıkarılmış, dolayısılyla } \\
\text { orman suçları için genel } \\
\text { af çıkarılabilmesi } \\
\text { olanaklı hale } \\
\text { getirilmiştir. }\end{array}$ \\
\hline
\end{tabular}


Değişiklik teklifi ile ilgili görüşmeler Millet Meclisinde 13 ve 14 Nisan 1970 tarihli birleşimlerde, değişlik teklifi ile ilgili genel görüşmeler ve değişiklik önergeleri şeklinde yapılmış ve değişiklik teklifinde değişiklik yapılmasıyla ilgili önergeler reddedilmiştir. Millet Meclisi 13.4.1970 tarihli birleşiminde, Anayasa Komisyonunun, teklifin 48 saat geçmeden görüşülmesi ve öncelikle (diğer konulardan önce) görüşülmesi önerileri kabul edilmiş ve teklif görüşülmeye başlanmıştır (TBMM, 1970a).

Anayasa'nın 131. maddesinin değiștirilmesine ilișkin teklif Millet Meclisinde görüșülüp kabul edildikten sonra Cumhuriyet Senatosuna gelmiş ve 16 Nisan 1970 tarihinde Cumhuriyet Senatosunda görüşmeler başlamıştır. 16 Nisan tarihli birleşimde değişiklik teklifi ile ilgili görüşmeler tamamlanmış ve teklif kabul edilmiştir. Teklif hakkındaki ikinci görüşme ise, her ne kadar Cumhuriyet Senatosu İçtüzügüne göre beş gün sonra yapılması gerekse de, Senato Başkanlığına verilen bir önergenin kabul edilmesiyle öne alınarak 17 Nisan 1970 tarihinde gerçekleştirilmiştir. Cumhuriyet Senatosu görüşmelerinde de Millet Meclisi görüşmelerinde olduğu gibi teklif üzerindeki asıl tartışmalar birinci gün birleşiminde yapılmış, ikinci gün birleşiminde herhangi bir tartışma olmadan yalnızca oylama yapılmış ve değişiklik teklifi 141 kabul oyuna karşı 16 ret oyuyla kesin olarak kabul edilmiştir.

Millet Meclisi görüşmelerinde altı milletvekili kendi adlarına, dört milletvekili de parti grupları adına söz almıştır. Ayrıca Anayasa Komisyonu Başkanı da sorulan bazı sorulara yanıt vermek amacıyla söz almış̧ır. Millet Meclisinde yapılan görüşmeler değişiklik teklifinin içeriğine uygun olarak bazı temel konu başlıklarının etrafında yoğunlaşmıştır. Bunlar; orman köylüsünün durumu, orman suçları için genel af çıkarılamaması, ormanların gözetilmesi ve işletilmesinde devlet ile orman köylüsünün işbirliği ve orman niteliğini kaybeden alanlardır. Cumhuriyet Senatosu görüşmelerinde ise altısı kişisel görüşlerini üçü grup görüşlerini dile getirmek üzere toplam dokuz senatör söz almıştır. Cumhuriyet Senatosundaki tartışmalar da genel olarak aynı başlıklar altında seyretmiş̦tir (TBMM, 1970b). Cumhuriyet Senatosunda bir senatör tarafından okunan İstanbul Üniversitesi Orman Fakültesi bildirisi ile Orman Mühendisleri Odası bildirisi ayrı bir tartışma konu başığını oluşturmuştur. Aşağıda, teklifin her iki organda görüşülmesi sırasında TBMM üyeleri tarafından gündeme getirilen temel yaklaşımlar özetlenmiştir.

\section{Orman köylüsünün durumu}

Millet Meclisinde Anayasa değişiklik teklifi ile ilgili olarak söz alan hemen bütün konuşmacılar orman köylüsünün durumundan ve onların yaşadığı sorunlardan söz etmiştir. Konuyla ilgili değinilen temel noktalar aşağıda maddeler halinde sıralanmıştır:

- Orman köylüsünün son derece olumsuz yaşam koşullarına sahip olduğu belirtilmiştir (bütün konuşmacılar)

- Devletin ormanların korunmasına ağılık veren ormancılık politikaları eleştirilmiş, toplum ve ormanın birbirine zarar verir hale geldiği, bunun etkisiyle ve tarımsal üretimin veriminin düşmesiyle orman köylerindeki yaşam koşullarının daha kötüye gittiği vurgulanmıştır (Ömer Buyrukçu).

- Devletin Anayasa gereği olan orman köylüsünün kalkındırılmasına yönelik görevini yerine getirmemesi, bu konuda gerekli ödeneğin bütçede yer almaması eleştirilirken, ormanı koruyucu önlemlerden vazgeçerek kırsal kalkınmanın olanaklı olmayacağı üzerinde durulmuştur. Bu çerçevede kooperatifçiliğin desteklenmesi, orman işletmelerinin oluşturacakları fonla kooperatifleri desteklemesi ve orman sanayiinin geliştirilmesi önerileri gündeme gelmiştir (Ali Rıza Uzuner).

- Orman köylüsünün kalkındırılmasının ön koşulu olarak önceliğin ormanı korumaya değil insana verilmesi bu yolla insanların kalkındırılması ile ormanların korunmasının mümkün olabileceği belirtilmiştir (Bülent Ecevit).

- Orman-insan ilişkilerinin önemi vurgulanmış, ikisinin birlikte ele alınması ve gelecek nesillerin de dikkate alınarak, ormanların korunmasının önemine işaret edilmiştir (Mehmet Nebil Oktay).

- Orman köylüsünün sorunlarının çözülmesinin önceliğine değinilmiştir (Orhan Cemal Fersoy).

- Orman köylüsünün sorunlarının çözülmesi için Anayasa dışında, kanunlarda yer alan bazı hükümlerin uygulamaya aktarılması gerektiği üzerinde durulmuş, orman köylüsünün topraklarının verimsiz olduğu bu nedenle -Orman Yasası'nın 13. maddesi gereği- her sene 50 milyon lirayı Türk köylüsüne aktarılması ve orman içinde kalkınması mümkün olmayan insanların başka yere nakledilmesinin gerekliliği vurgulanmıştır (Hilmi İşgüzar).

Orman köylüsünün durumu Millet Meclisi görüşmelerinde olduğu gibi Cumhuriyet Senatosu görüşmelerinde yapılan konuşmalarda da yer almış, senatörler genel olarak orman köylüsünün sosyo-ekonomik açıdan çok kötü koşullara sahip olduğunu ve bu koşulların kabul edilmesinin mümkün olmadığını dile getirmişlerdir. Aşağıda senatörler tarafından yapılan konuşmalardaki orman köylüsünün durumuna ilişkin kısımlar özetlenmiştir: 
- Orman ve orman köylüsü problemlerinin, Anayasa'nın 131. maddesinin değiștirilmesiyle çözülemeyeceği, aksine ormanlar ve orman köylülerinin zararına sonuçlar doğuracağı belirtilmiştir (Mucip Ataklı).

- Orman kaynakları, yöneticiler ve yakın çevresinde yaşayan halk ilişkilerinin düzenlenmesi ve bu ilişkiler çerçevesinde geçim kaynaklarının oluşturulması gerekliliği belirtilmiştir (Fehmi Baysoy).

- Orman köylülerinin mevcut sistem içinde sömürüldüğü ve sistemin bütünüyle değiştirilmesi gerekliliği ifade edilmiştir (Fikret Gündoğdu).

- 6831 Sayılı Orman Yasasının hüküm ve uygulamalarından kaynaklanan sorunların etkisiyle orman köylüsünün durumunun kötüleştiği ve bu kesime ilişkin yaklaşımların ortak ulusal hedefler kapsamında ele alınmasının önemine değinilmiştir (Lütfi Bilgen).

- 6831 sayılı Orman Kanunun çok sert olduğu ve orman köylüsünün ezilmesine neden olduğu görüşü ortaya konulmuştur (Ömer Ucuzal).

- Anayasanın 131. maddesi hazırlanırken ormanın korunmasının ön planda olduğu ancak köylünün durumunun ve korunmasının düşünülmediği ifade edilmiştir (Nahit Altan).

\section{Orman suçları için genel af çıkarılması}

Millet Meclisinde gerçekleşen görüşmelerin önemli tartışma konularından biri de teklifin orman suçları için genel af çıkarılamayacağına ilişkin hükmün Anayasa'dan çıkarılmasını öngören kısmı ile ilgili olmuştur. Bu konuda milletvekilleri tarafından dile getirilen aleyhte görüşleri şu şekilde özetlemek olanaklıdır:

- Orman köylüsünün yoksulluk ve çaresizlikten dolayı suç işlediği Anayasa'da "orman suçları için genel af çıkarılamaz" şeklindeki hükmünün bu durumu değiştirmeyeceği anlatılmıştır (Ali Rıza Uzuner, Hilmi İşgüzar).

- Devletin orman köylüsünün kalkındırılması için yapması gerekenleri yapmaması, bunun yerine af kanunları ile çözüm aranmasının doğru bir yaklaşım olmadığı ortaya konulmuştur (Ali Rıza Uzuner).

- 1950-1958 yılları arasında orman suçları için dört farklı af kanunun çıkarıldığı belirtilerek, sonuçlarının orman köylüsünün sorunlarını çözmek açısından hiçbir yarar üretmediği belirtilmiştir (Ali Rıza Uzuner).

- Af kanunları ile suçların azalması arasında bir ilişkinin bulunmadığına işaret edilmiştir (Hilmi İşgüzar).

- Af ile ilgili hükümlerin anayasaya girmesinin temel sebebinin orman alanlarından, köylünün kolaylıkla ve karşılıksız yararlanmasını destekleyen siyasi yaklaşımların sonucu olduğu ve asıl olanın bu siyasi tutumun değiştirilmesi olduğu ifade edilmiştir (Sadi Koçaş).

Orman suçları için genel af çıkarılamayacağına ilişkin Anayasa hükmünün 131. maddeden çıkarılmasına ilişkin aleyhte dile getirilen bu görüşlere karşılık olarak değişiklik teklifi lehinde dile getirilen görüşler de şu şekildedir:

- Türkiye'de kaçakçılık ve insan öldürme gibi suçlara ilişkin af çıkarılırken yoksulluktan orman suçu işleyenlerin anayasaya dayanarak affedilememesi yaklaşımı eleştirilmiştir. Anayasa'nın ilgili hükmünün orman suçlarını azaltmadığına değinilmiştir (Bülent Ecevit).

- Anayasa'da yapılacak değişikliğin bir af kanunu olmadığg, af çıkarma yetkisinin Mecliste olduğu belirtilmiştir (Bülent Ecevit, Vahit Bozatli).

- Öldürme, ırza geçme gibi suçlara ilişkin af çıkarılabiliyorken orman suçlarıyla ilgili af çıkarılamaması yaklaşımının vatandaşlar arasında eşitsizliğe yol açtı̆̆ı belirtilmiştir (Mehmet Nebil Oktay).

- Modern anayasaların hiç birisinde parlamentoların genel aflara ilişkin yetkilerini kısıtlanmadığına değinilmiştir (Orhan Cemal Fersoy).

- Anayasa'nın orman suçları için genel af çıkarmayı yasaklayan hükmünün sert bir hüküm olduğu ve uygulamada aksaklıklara yol açtığı bu nedenle söz konusu hükmün adil olmadığı ifade edilmiştir (Sadi Koçaş). ${ }^{4}$

Cumhuriyet Senatosu görüşmelerinde de Millet Meclisi görüşmelerinde olduğu gibi, üzerinde olumlu ya da olumsuz en çok görüş bildirilen konu "orman suçları için genel af çıkarılamaz" hükmünün Anayasa'dan çıkarılması olmuştur. Bu değişikliğin aleyhinde dile getirilen görüşler şu şekilde özetlenebilir:

- $\quad 1950$ ’li yıllarda çıkarılan dört af kanunun ormanların tahribini hızlandırdığı, orman suçlarını teşvik ettiğ ifade edilmiş, bu kapsamda orman suçlarını \% 500 artarak 100 binin üzerine çıkmasına zemin hazırlandığı

\footnotetext{
${ }^{4}$ Sadi Koçaş Anayasa'nın ilgili hükmünün bazı orman suçlarının (ormanı yakmak, kaçakçılık yapmak, bina ve tesis inşa etmek vb.) affedilmesini engelleyecek, fakat bazı suçların da affedilebilmesine olanak verecek şekilde düzenlenmesini önerdiğinden, konuşmasında hem lehte hem de aleyhte görüşler dile getirmiştir.
} 
belirtilmiştir. Mevcut haliyle ortaya çıkan durumun sosyal adaletsizliğin artışına neden olduğu, orman köylüsünün sosyal ve ekonomik açıdan sorunlarının arttığı belirtilmiştir. Affın hiçbir ekonomik ve sosyal yarar sağlamayacağı, af yerine kısa ve uzun vadeli köy kalkınması önlemlerinin alınması yoluyla suça iten etkenlerin ortadan kaldırılması gerekliliği vurgulanmıştır (Mucip Ataklı).

- Orman köylüsünü suç işlemeye iten temel faktörün yoksulluk olduğu ve bu kesime verilen cezaların adil olmadığı belirtilmiş, orman köylüsünün mevcut sistemde sömürüldüğ̈̈ ifade edilerek, af çıkarılmasının sorunları çözmeyeceği söylenmiştir (Fikret Gündoğdu).

Görüş bildiren senatörlerin çoğu değişiklik lehinde konuşmuşlardır. Bu görüşler özetle şu şekildedir:

- Yapılacak değişikliğin bir af kanunu çıkarmak olmadığı, yalnızca bunun olanaklı hale geldiği belirtilmiştir (Fikret Gündoğdu, Mustafa Tığlı, Nahit Altan).

- Orman suçlarında \%30 oranında bir azalma olduğu ancak bu durumun 131. madde ile ilişkisi olmadığ1, 1sınmak ve pişirmek amacıyla kömür ve gaz kullanımının artmış olmasının etkisi olduğu ifade edilmiş ve bütün suçlar gibi orman suçlarının da affedilebilir olması gerekliliği vurgulanmıştır (Mustafa Tığlı).

- Ormanda gerçekten suç işleyenler yerine bazı görevliler ile husumetleri nedeniyle suçluymuş gibi gösterilenlerin bulunduğu ve ilgili tutanakların sayısının binleri geçtiği gündeme getirilmiştir (Ömer Ucuzal).

- Pek çok suçu işleyenlerin, casusluk yapanların bile affedilebilmekte, fakat orman suçu işleyenlerin affedilememekte olması eleştirilmiştir (Nahit Altan).

- Anayasada orman suçlarının affedilemeyeceğine ilişkin hükmün eşitlik ilkesine uygun olmadığ vurgulanmıştır (Orhan Kürümlüoğlu).

\section{Ormanların gözetilmesi ve işletilmesinde devlet ile orman köylüsünün işbirliği}

Millet Meclisinde yapılan görüşmeler sırasında üzerinde sıkça durulan konulardan biri de 131. maddenin 4. fıkrasında yapılması teklif edilen değişiklikle ilgilidir. $\mathrm{Bu}$ fikranın özgün halinde orman köylüsünün kalkındırılması ve gerekirse başka yerlere yerleştirilmelerinin kanunla düzenleneceği belirtilmektedir. Değişiklik teklifiyle bu fikraya, ormanların gözetilmesi ve işletilmesinde devletle bu halkın işbirliği yapması da eklenmiştir. Söz konusu değişiklik teklifine ilişkin dile getirilen aleyhte görüşler aşağıda özetlenmiştir:

- Ormanların gözetilmesi ve işletilmesine orman köylüsünün iştirak ettirilmesinin 2. fikradaki hükme (Devlet ormanları devlet tarafından yönetilir ve işletilir) aykırı olduğu belirtilmiştir (Ömer Buyrukçu).

- Orman işletmeciliğinin, kendine has özellikleri olduğu, bu işin ormancılık teşkilatının görevi olduğu ve halkın orman işletmeciliğine katılımının uygun olmadığ 1 dile getirilmiştir. Halkın orman işletmeciliğine katılımı konusunun suiistimale açık bir yaklaşım olduğu ifade edilmiştir (Ali Rıza Uzuner).

Teklifin lehinde dile getirilen görüşler ise özetle şu şekildedir:

- Ormanların mülkiyetinin ve korunması sorumluluğunun devlete ait olması esası çerçevesinde halkın orman işletmeciliğine katılımının ormanları koruma yönünden olumlu sonuçlar doğuracağı belirtilmiştir (Bülent Ecevit).

- Köylü ile işbirliğinin çok önemli olduğu; bu kapsamda devlet işletmeciliğine ek olarak fabrikaların geliştirilmesi, orman ürünlerinin değerlendirilmesi gibi alanlarda da uygulamaların yapılmasının yararlı olacağı dile getirilmiştir (Orhan Cemal Fersoy).

- 131. maddedeki değişiklik ile ortak işletmeciliğin ve işbirliğinin öngörüldüğü, bunun olumlu sonuçları olacağı görüşü ortaya konulmuştur (Kemal Bağcioğlu).

- Devlet ile işbirliği yapması sayesinde orman köylüsü, orman ve devlet arasındaki ilişkilerin güçleneceği ifade edilmiştir (Hasan Tosyalı).

$\mathrm{Bu}$ konu, Millet Meclisi görüşmelerinde olduğu gibi Cumhuriyet Senatosu görüşmelerinde de konuşmalar içerisinde önemli yer edinmiştir. Konu hakkında dile getirilen görüşler özetle şu şekildedir:

- Teklifin kabul edilmesi durumunda 131. maddenin 2. fikrası ile 4. fikrasının çelişeceği, 2. fikrada devletçilik esas iken 4. fikrada devletle köylünün işbirliği yaptığı karma bir sistem tanımlanmasının sakıncalı olacağı ifade edilmiştir (Mucip Ataklı).

- Devletle köylünün işbirliğini öngören değişiklik; sözde kalan orman köylüsü ile idare ilişkisini somutlaştıracak, orman köylüsüne güven telkin edecek ve onları ormana biraz daha yakınlaştıracak bir hüküm olarak değerlendirilmiştir (Fehmi Baysoy). 
- 6831 Sayılı Orman Yasası'nın örneğin 26. ve 40. maddelerinin orman işletmeciliğinde devlet ile köylünün işbirliğini tanımladığı ve bu durumun Anayasa'ya aykırı olmadığı belirtilmiştir. Bu yaklaşımın Anayasa'da da yer alması ile köylü-devlet ilişkisinin güçleneceği, sermaye ve varlığın devlete, işgücünün ise köylüye ait olduğu ve kararların ortaklaşa verildiği bir işletmeciliğin başlaması ile modern ve verimli bir yaklaşımın oluşacağ1 görüşü gündeme taşınmıştır (Fikret Gündoğan).

- Değişiklik önerisinde "işbirliği”nin dar anlamda (mal ve hizmet üretimi) ya da geniş anlamda (üretimden tüketime giden bütün aşamaları) işletmeciliği kapsadığının açıklığa kavuşturulması gerekliliği üzerinde durulmuştur. Söz konusu değişiklik ile orman köylüsüne tanınan yasal yararlanma hakları, köylüler arasındaki ilişkiler, ürün ve hizmetlerin sürekliliği konularında sorunların yaşanmasına yol açabileceği belirtilmiştir. Ayrıca bu değişiklik ile devletin ormanlar üzerindeki tasarrufu ile koruma, gözetim, denetim, yönetim ve işletme gibi inisiyatiflerinde gevşemelere yol açabileceği görüşü dile getirilmiştir (M. Faik Atayurt).

- Söz konusu anayasa değişikliği ile oluşacak düzenin köylünün devlet ve ormana yabancılığını sona erdireceği belirtilmiştir (Lütfi Bilgen).

- İlgili değişiklik ile devlet köylü işbirliğinin sağlanacağı, köy halkının kalkındırılması ve orman suçlarının azaltılması amaçlarına katkı sağlayacağı ifade edilmiş, işbirliğinin kapsamının ise çıkarılacak kanunlarla belirlenmesi gerekliliğinden söz edilmiştir (Mustafa Tı̆̆lı).

- Orman işletmeciliğinde devletle köylünün işbirliğini öngören değişikliğin, demokratik ülkelerde orman servetinin devamlılığı ve korunması için uygulanan bir yöntem olduğu dile getirilmiştir (Ömer Ucuzal).

\section{Orman sinırlarının daraltılması}

Getirilen değişiklik teklifi ile Anayasa'nın yürürlüğe girdiği tarihten önce bilim ve fen bakımından orman niteliğini yitirmiş alanların orman sınırları dışarısına çıkarılması olanaklı hale getirilmek istenmiştir. Teklifin bu kısmı ile ilgili Millet Meclisinde dile getirilen ve teklifi benimsemeyen ya da bazı değişikliklerin olması şartıyla benimseyen görüşler kısaca şu şekildedir:

- İlgili değişiklik teklifinin ormanların aleyhine bir ifade taşıdığı, ormanların genişletilmesi için gerekli olan alanların otlak sahasına dönüştürülmesi olasılığı üzerinde durulmuştur (Ömer Buyrukçu).

- Anayasanın yürürlüğe girdiği tarihten önce ve sonrasındaki arazi değişiminin belirlenmesindeki güçlüklere değinilmiş ve durumunun siyasi açıdan özünden saptırılabilecek bir unsur olduğu vurgulanmıştır. Belirtilen çerçevede söz konusu alanların kullanım hakkı ile ilgili sorunların gündeme gelebileceği gibi suç işlemeyi teşvik edici bir boyut taşıdığı ve orman tahribini artırıcı bir faktör olacağ belirtilmiştir (Ali Rıza Uzuner).

- 131. maddenin 1. fikrası ile devlete ormanları koruma ve genişletme yetkisi verilirken söz konusu madde ile ormanları daraltma yetkisi verildiği, bu iki yetkinin de çeliştiği için uyumlu olacak şekilde düzeltilmesi gereği üzerinde durulmuştur (Kenan Mümtaz Akışı).

- "Bilim ve fen bakımından" ifadesinden sonra "iklim, su ve toprak rejimine zarar vermeyen” ifadesinin eklenmesi gerekliliğine vurgu yapılmıştır. $\mathrm{Bu}$ yolla çevresel-ekolojik işlevlere sahip orman alanlarının vatandaşlara verilmesinin önüne geçileceği belirtilmiştir (Hilmi İşgüzar).

Teklifi destekleyen görüşler ise özet olarak şu şekildedir:

- Daha önce bilim ve fen bakımından orman niteliğini kaybeden alanların orman rejimi dışına çıkarılması için bir kanun (663 Sayılı Kanun) çıkarıldığı ancak Anayasa Mahkemesi tarafından iptal edildiği belirtilmiştir. İlgili alanlardan bölgede yaşayan halkın yararlandırılmasının yasal olarak olanaklı hale getirilmesi için Anayasada değişiklik yapılmasının gereği vurgulanmış, bu yolla bölge halkının yoksullukla mücadelecisine destek olunabileceği ve dolayısıyla ormanların korunabileceği ifade edilmiştir (Bülent Ecevit).

- Anayasa'nın yürürlüğe girdiği tarihten önce bilim ve fen bakımından orman vasfını kaybetmiş, bağ haline gelmiş veya zeytinlik haline gelmiş, ülke ekonomisine milyonlarca döviz getirebilecek alanları, orman alanı olarak nitelemenin ekonomik açıdan büyük bir kayba yol açtığı gündeme getirilmiştir (Mehmet Nebil Oktay).

- Günün koşulları gereği orman sınırlarının daraltılmasının bir zorunluluk olduğu ve parlamentonun da buna karşı çıkmaması gerektiği ifade edilmiştir (Kenan Mümtaz Akışı).

Orman niteliğini yitiren bazı orman alanlarının orman sınırları dışarısına çıkartılarak orman sınırlarının daraltılmasına yol açan değişiklikle ilgili olarak Cumhuriyet Senatosunda dile getirilen görüşler şu şekilde özetlenebilir: 
- Değişikliğin uygulanabilir olmadığı, Anayasa'nın yürürlüğe girdiği tarihten önce orman niteliğini kaybetmiş yerlerin saptamasının olanaklı olmadığı gibi, o tarihten sonra da benzer duruma gelen yerlerin ilgili hükme uydurulmasının olanaklı olabileceği bu nedenle de orman yağmasına yol açabilecek bir nitelik taşıdığ 1 vurgulanmıştır (Mucip Ataklı).

- Orman sınırları belirlenirken, ulusal çıkarlar ve köylünün çıkarlarının dikkate alınması, orman niteliğini kaybetmiş, bağ-bahçe haline gelmiş alanlardan köylünün geçimini sağlamasının olanaklı hale getirilmesinin esas olması gerekliliğine işaret edilmiştir (Fehmi Baysoy).

- Çok eski tahdit haritaları nedeniyle orman olarak görünen fakat orman olmayan, orman olması da olanaklı olmayan açıklık ve boşlukların tarıma dayalı ya da tarımsal endüstriye dayalı bir uğraş için kullanılmasının ekonomik gelişme açısından önemli olduğu vurgulanmıştır (Fikret Gündoğdu).

- 663 Sayılı Yasa'yı iptal eden Anayasa Mahkemesi kararı gereği eski tahdit sınırlarına giren her yerin orman sayıldığg1, buna göre halkın ve ormanın yararına yeni bir orman tahdidi yapılmasının mümkün olmadığı ifade edilmiştir (Lütfi Bilgen).

- Orman niteliğini kaybetmiş, fındıklık, portakallık vb. haline gelmiş ve köylü tarafından kullanılmakta olan arazilerin eskiden beri sorun olduğu ve bu değişiklikle çözülmüş olacağı ifade edilmiştir (Mustafa Tiğl1).

- Söz konusu değişikliğin 663 Sayılı Yasa’nın getirdiği yeniliği onayladığı ve bu yasanın, Anayasa'da böyle bir düzenleme bulunmadığı için Anayasa Mahkemesi tarafından iptal edildiğine dikkat çekilmiştir (Ömer Ucuzal).

- Tapulu zeytinliklerin mevcut işleyişte orman sınırları içine alınmasının adil olmadığı belirtilmiştir (Nahit Altan).

- Bütün binaları ile birlikte orman sayılan köylerin sayılarının fazla olduğu, bu durumun yarattığı sorunları çözebilmek için değişiklik teklifinin desteklenmesi gerektiği ortaya konulmuştur (Orhan Kürümoğlu).

\subsection{Orman Mühendisleri Odası ve Orman Fakültesi bildirileri}

Orman Mühendisleri Odası ve Orman Fakültesi bildirileri Milli Birlik Grubu adına yaptığı konuşmada Mucip Ataklı tarafından Cumhuriyet Senatosunun gündemine getirilmiştir. Mucip Ataklı konuşmasında, ormancılıkla ilgili kişi ve kuruluşların değişiklik teklifi ile ilgili uyarılarının takdirle karşılanması gerektiğini söyleyerek, önce Orman Mühendisleri Odası tarafından yayımlanan bildiriyi üyelere okuyarak aktarmıştır.

Orman Mühendisleri Odası tarafından yayımlanan bildiride dile getirilen görüşler özet olarak şu şekildedir:

- Orman suçları için genel affı engelleyen hüküm Anayasa'ya, sık sık çıkarılan af yasalarının sorunu çözmekten uzaklığı ve ormanların tahribine yol açması nedeniyle halktan gelen af taleplerine karşı iktidarları korumak ve muhalefetin de bunu istismar etmesini engellemek amaciyla konulmuştur. Hükmün Anayasa'ya konmasını gerektiren şartlarda bugün herhangi bir değişiklik bulunmamaktadır.

- Ülkenin doğal koşulları oldukça hassas olduğundan ormanların korunması açısından öncelikli konulardan biridir.

- Orman köylüsünü kalkındırmak, sorunlarını çözmek için gerekli çalışmalar yapılmamış, her yıl bütçeye konulması gereken 50 milyon lira bütçeye konulmamıştır.

- Önceki dönemlerde çıkarılan af kanunları sonrasında orman suçları son derece yüksek oranlarda artmıştır.

Orman Fakültesi tarafından yayımlanan bildiriyi aktarmaya başlayacağı sırada Mucip Ataklı, oturum başkanı tarafından; bildirilerin bütün üyelere zaten dağıtıldığını, tamamını okumak yerine özünün ifade edilmesinin daha doğru olacağı yönünde uyarılmıştır. Bu uyarı üzerine Cumhuriyet Senatosu Tabii Üyesi Mehmet Özgüneş "Tarihe vesika verelim." diyerek müdahale etmiştir. Ardından Mucip Ataklı ile başkan arasındaki diyalog şu şekilde sürmüştür:

Mucip Ataklı: Sayın başkan, bildiriler çok kısa. Sonra, gözlere atılan bu bildirileri hiçbir üyenin okuduğunu da sanmiyorum.

Başkan: Okumadiysa zabittan da okumaz. O halde hiçbir fayda temin etmez.

Mucip Atakll: Tarihe vesika veriyoruz. Müsaade buyurun, sözümü kesmeyiniz, konuşmaya devam edeyim.

Bu diyalogun ardından Mucip Ataklı, Orman Fakültesi tarafından yayımlanan bildirinin tamamını okumuştur. Orman Fakültesi tarafından yayımlanan bildirinin önemli noktaları ise şu şekilde özetlenebilir:

- Fakültemiz son milletvekili seçimlerini izleyen günlerde yayımladığı bildiride orman suçları için genel af çıkarılmasını engelleyen hükmün Anayasa'dan çıkarılmasının doğuracağı sakıncaları dile getirmiş; orman köylülerinin sorunlarını çözmenin yolunun af çıkarmak değil sosyo-ekonomik önlemler almak olduğunu belirtmiş ve halk-orman ilişsilerinin düzenlenmesi hakkında bir broşür yayımlamıştı. 
- Af konusu, devlet ormanlarının devlet eliyle işletilmesine aykırı hükümler getirilmesi ve ormanların daraltılması konusundaki adımlar bilimsel değil siyasi düşüncelere dayanmaktadır.

- Suç nedenlerini ortadan kaldırmadan yapılacak af düzenlemesi suçları artıracak, ormanları azaltacaktır.

- Şimdiye kadar dünya literatüründe topraklarını yellere ve sellere kaptıran, ormanlarını keçilere yedirten bir ülke olarak nitelendirilen Türkiye, bundan sonra ormanlarını bilimsel gerçeklere aykırı bilimsel görüşlere harcayan bir ülke olarak tanımlanacaktır.

- Yakın bir gelecekte yeniden ağaçlandırılması ve orman haline getirilmesi kaçınılmaz bir zorunluk halinde karşımıza çıkacak olan bu alanları milyarlar harcamak ve uzun yıllar beklemek suretiyle vatan topraklarına yeniden katmak zorunda olacak olan bu vatan çocuklarımız ve torunlarımız bizleri her halde hayırla anmayacaklardır.

- Fakültemiz, islenen bu yanlış politik tutumu tasvip etmediğini ve sayın parlamento üyelerini tarihi sorumluluğu çok büyük olan kararlarını alırlarken bir kere daha uyarmak istediğini kamuoyuna duyurmayı bir görev saymaktadır.

Cumhuriyet Senatosu üyesi Mucip Ataklı daha sonra da Türkiye Ormancılar Cemiyeti, Orman Mühendisleri Odası, Orman Yüksek Mühendisleri Sendikası, Türkiye Tabiatını Koruma Cemiyeti ve Yeşil Türkiye Ormancılar Cemiyetinin ortaklaşa yayımlamış oldukları bildirinin önemli noktalarını aktarmıştır. Bilimsel ve mesleki kuruluşlarla sivil toplum kuruluşları tarafindan yayımlanan bu bildirilerle ilgili olarak iki senatör görüş belirtmiştir. Bu görüşler özet olarak şu şekildedir:

- Görüş belirten bilim adamlarına, değerli ormancılara biz de bazı sorular sorma hakkına sahibiz. Ormanları korumak için devlet bütçesinden yapılan harcamalar ile ormanlardan elde edilen gelirler karşılaştırıldığında harcamalar lehine büyük bir fark bulunmaktadır. Dağ başında, ışıklı lambalarla burası falan işletmedir diye ilan yapılırken 100 metre ileride lambasına gaz bulamayan, çam çırası ile geçinen insanlar yan yana yaşarsa, biz Anayasa'nın 131. maddesindeki sert hükümleri yumuşatıp yeni hükümler getirmeye mecbur kalırız. 33 yıldır kaç hektar orman yetiştirilmiş, bu ormanlardan ne kadar üretim yapılmıştır? Gölbaşı'na giderken Büyük Atatürk Ormanı diye bir alan ayrılmış. Üç beş çam fidanı dikmişler. Ona da sahip olamamışlar. Bir yıl önce baştanbaşa yanmış. Hesap soran arkadaşlara biz de vazifelerini hatıllatmak zorundayız (Ömer Ucuzal).

- Bugün dolabımı açtığımda bazı bildiriler buldum. Bu bildirilerin aşağı yukarı aynı üslupla yazılmış olması dikkatimi çekti. Bunlar bir ya da birkaç teşekkülün görüşlerini dile getiren bildirilerdir. Ancak, aleyhte görüş belirtirken bile olumsuz yanları ile birlikte olumlu yanlarının da değerlendirilmesini, ağır basan ya da hafif gelen yönlerin vurgulanmasını beklerdim (Orhan Kürümlüoğlu).

\section{Tartışma}

Türkiye'de ormancılıkla ilgili çalışmalar daha eski tarihlere dayansa da ulusal ormancılık politikasının bilimsel bir temele dayalı olarak şekillenmesi ile ormanların korunması ve geliştirilmesi çalışmalarının bütünlük kazanması 1937 yılından itibaren söz konusu olabilmiştir. Çok partili rejime geçişten sonra yaşanan siyasal, sosyal ve ekonomik süreç bir yandan kırsal yoksulluğu artırmış ve ormanlar üzerindeki sosyal baskıyı şiddetlendirmiş, diğer yandan da ormanların korunmasını güçleştirici politikaları ortaya çıkarmış, ormanları siyasal propaganda malzemesi haline getirmiştir. 1960 yılında yönetime el koyan askeri hükümet tarafindan hazırlanan yeni anayasada, bu gelişmelerin bir sonucu olarak değerlendirilebilecek ve ormanların korunmasını garanti altına alacak hükümler yer almıştır. Parlamenter sisteme dönülmesinin ardından anayasanın ormanları koruyucu kurallarını aşamayan siyaset, çözümü anayasayı değiştirmekte bulmuş ve 1970 yılında Anayasa'nın 131. maddesinin değiştirilmesi ile ilgili teklif TBMM gündemine gelmiştir.

TBMM'de anayasa değişikliği ile ilgili görüşmeler son derece hızlı bir şekilde gerçekleştirilmiştir. Millet Meclisi ve Cumhuriyet Senatosunda değişiklik teklifi hem öne alınarak hem de iki görüşme arasında olması gereken süre azaltılarak süreç hızlandırılmıştır. Her iki organda da söz alan milletvekili ve senatör sayısı bir anayasa değiş̧ikliği için son derece az denecek düzeydedir. TBMM'de değişiklik teklifi ile ilgili görüşmeler büyük ölçüde orman köylüsü ekseninde gerçekleşmiş, değişikliği savunanlar da karşı çıkanlar da orman köylüsünün içinde bulunduğu sosyo-ekonomik koşulların zorluğunu vurgulamışlardır. Orman köylüsünün yaşam koşulları günümüzde de sorunlu yapısını devam ettirmektedir. Orman köyleri çoğunlukla sarp araziler üzerinde, kent merkezlerinden uzakta bulunmakta, eğitim ve sağlık hizmetlerine erişim yetersiz, gelir düzeyi ülkenin en altında yer almakta ve bu köylerden kentlere yoğun bir göç yaşanmaktadır (Günşen ve Atmiş, 2015). Göç olgusu özellikle 1980'li yıllardan itibaren hız kazanmıştır. 1970 yılında 16 bin orman köyünde yaşayan orman köylüsü nüfusu 7 milyon 954 bin iken 1980 yılında orman köyü sayıs1 17 bin 568'e orman köylüsü nüfusu da 10 milyon 161 bine yükselmiştir. Bu sayılar sırasıyla 1990 yılında 19 bin 62 ve 8 milyon 822 bin, 
1997 yılında da 18 bin 688 ve 7 milyon 50 bin olarak saptanmıştır (Konukçu, 1999). 2019 yılı itibariyle toplam orman köyü sayısı 22 bin 941 ve bu köylerde yaşayan orman köylüsü nüfusu ise 6 milyon 970 bin olarak belirlenmiştir (OGM, 2020). Görüldüğü gibi orman köylüsü nüfusu 1980'lere kadar artmış, 1980'lerden itibaren ise düşüşe geçmiştir ve bu düşüş günümüzde de devam etmektedir.

Anayasa'nın yapıldığı ve 131. maddede değişikliğin gündeme geldiği dönemlerde orman köylerinin sorunlarının çözülmesi için yapılması gerekenlerin neler olduğu hem kamusal belgelere (OGM, 1963; DPT, 1972) hem de bilimsel ve mesleki yayınlara (İnal, 1959; Üçüncü, 1970) ayrıntılı olarak yansımıştır. Bu belge ve yayınlarda, genel olarak orman köylülerinin gelir düzeylerinin artırılması, bunun için tarım ve hayvancılık dışında alternatif geçim kaynaklarının yaratılması; eğitim ve sağlık gibi temel sosyal hizmetlerin orman köylerinde yaygınlaştırılması ile yine temel altyapı hizmetlerinin (yol, içme ve sulama suyu, elektrik vb.) geliştirilmesi çözüm önerileri arasında sıklıkla vurgulanmıştır. Benzer şekilde, bulundukları yerlerde kalkındırılması olanaklı görülmeyen orman köylerinin başka yerlere taşınması da sıkça dile getirilmiş ve 6831 Sayılı Orman Yasası'nın 13/b maddesi bu amaçla düzenlenmiştir. Bulundukları yerde kalkındırılmaları olanaklı görünen orman köylerinin kalkındırılması için aynı yasanın 13/a ve Ek 3. maddelerince Ziraat Bankası'nda bir fon oluşturulmuştur. Millet Meclisi ve Senato görüşmelerinde de dile getirildiği üzere bu fona hazine tarafından her yıl konulması gereken 50'şer milyon lira konulmamış, fona 1963 yılına kadar yalnızca 7,5 milyon lira aktarılabilmiştir. Aktarılan bu paranın tamamının orman köylülerinin kalkındırılması amacıyla kullandırılmaması, uygun köy ve ailelerin seçilememesi, verilen krediden faiz alınması ve organizasyon yetersizlikleri gibi sorunlar yaşanmıştır (OGM, 1963).

Hal böyleyken, anayasa değişikliğini savunanlar, sosyo-ekonomik açıdan zor koşullara sahip orman köylüsünün sorunlarının çözülebilmesi için bu değişikliklerin yapılması gereğini dile getirmişlerdir. Değişikliğe karşı çıkanlar ise mevcut sorunların çözümü ile önerilen değişikliğin neden-sonuç ilişkisi içerisinde olmadığını, orman köylüsünün sorunlarının çözülebilmesi için orman suçlarını affetmek ya da orman niteliğini kaybetmiş orman alanlarını orman rejimi dışarısına çıkararak tarım ve hayvancılığa kazandırmak yerine sosyo-ekonomik temelli çözüm yollarının uygulanması gerektiğini savunmuş, Anayasa'nın da bunu öngördüğünü fakat geçmiş hükümetlerin bu konuda adım atmadıklarını dile getirmişlerdir.

Burada önemle vurgulanması gereken konulardan birisi, kuşkusuz, orman köylülerine tanınmış olan ormanlardan yararlanma haklarıdır. Bu toplum kesiminin sahip olduğu koşullar göz önünde bulundurularak, ormancılıkla doğrudan ilgili ilk yasal düzenleme olan Orman Nizamnamesi (1870)'nden beri orman köylülerine bazı yararlanma hakları tanınmıştır ve zaman içerisinde yapılan çeşitli değişikliklerle bu haklar bugün de varlığını sürdürmektedir. Ne Millet Meclisi ne de Cumhuriyet Senatosu görüşmelerinde bu konuya değinilmemiştir. Yalnızca 1961-1970 yılları arasında sözü edilen bu hakların parasal karşılığı yıllık ortalama 130 milyon lira olarak hesaplanmıştır. 1960 yılında bu miktar 100 milyon lira dolayında iken 1970 yılında 200 milyon lirayı geçmiştir (Özdönmez, 1973b). Yukarıda belirtilen yıllık 50'şer milyon liranın orman köylülerini kalkındırmak amacıyla bütçeye konulamadığı bir dönemde ormanlardan orman köylülerine her yıl bundan çok daha fazla ekonomik yarar aktarılmıştır. Ne var ki ülkenin siyasetçileri bu durumu hesaba katmadan, orman köylüsünün sorunlarının çözülmesi meselesini yalnızca ormanlar üzerinden ele almış ve ormanlara bedel ödettirmeye devam etme arayışında olmuşlardır.

Anayasa değişikliği ile ilgili olarak Millet Meclisi ve Cumhuriyet Senatosu görüşmelerinde üzerinde en çok görüş belirtilen konu, orman suçları için genel af çıkarılmasını engelleyen hükmün değiştirilmesi olmuştur. Değişikliği savunanlar, özetle, bu değişikliğin bir af kanunu olmadığı, diğer suçlar için af çıkarma yetkisi TBMM'de iken orman suçları için bu yetkinin TBMM'nin elinden alınmasının hukuka uygun olmadığ orman köylülerinin ağır yaşam koşulları nedeniyle adeta zorunluluktan işlemek zorunda kaldığı orman suçlarının affedilememesinin adil olmadığı gibi gerekçeleri dile getirmişlerdir. Değişikliğe karşı çıkanlar ise orman suçları için özel af kanunu çıkarmanın mümkün olduğunu, Anayasa'nın genel af çıkarmayı engellediğini, önceki dönemlerde çıkarılan afların ne suçların azalması ne de ormanların korunması açısından olumlu sonuçlara yol açmayıp tersine olumsuz sonuçlar doğurduğunu, çıkarılan af kanunlarının köylüyü sömüren kaçakçıların işine yaradığını ve suçları doğuran nedenler ortadan kaldırılmayıp yalnızca af kanunu çıkarmanın işe yaramayacağını vurgulamışlardır.

$\mathrm{Bu}$ noktada hemen belirtmek gerekir ki, genel af ile özel af arasındaki temel fark, genel affın fiilin yalnızca cezasını değil suç oluşturma niteliğini de ortadan kaldırmasıdır. Oysa özel af, işlenen fiilin suç oluşturma özelliğini değil yalnızca cezasını ortadan kaldırır (Keyman, 1965; Özdönmez, 1973a).

Özdönmez (1973a) tarafından yapılan bir çalışma ile orman suçları ile çıkarılan af kanunları arasındaki ilişki ele alınmış ve orman suçlarına yönelik olarak çıkarılan af kanunlarının af müessesesinden beklenen yararları 
gerçekleştirmediği, tam tersine orman suçlarını artırıcı yönde etki yaptığı ortaya konulmuştur.

Anayasa'da yapılan değişikliğin ardından 1972 yılında "Bazı Orman Suçlarının Affına ve Bunlardan Mütevellit İdare Şahsi Haklarının Düşürülmesine Dair Kanun” TBMM gündemine gelmiş, teklif dönemin Orman Bakanı Prof. Dr. Selahattin İnal'ın karşı çıkmasına rağmen yasalaşmışıtır. Ancak kanun, Anayasa'nın "ormanların korunması ve geliştirilmesi" ilkesini bozacağı ve orman azalmasına yol açacağı gerekçesi ile Cumhurbaşkanlığınca veto edilmiş; araya giren cumhurbaşkanlığı seçimi ve hükümet değişikliğinin ardından benzer bir af kanunu yeniden TBMM'de kabul edilmiş ve yine Cumhurbaşkanlığınca tekrar görüşülmek üzere meclise iade edilmiştir. 1973 seçimlerinden önce kanunun yetiştirilmesi için çabalar olmuşsa da sonuç vermemiş ve af kanunu rafa kalkmıştır (Özdönmez, 1973a). Söz konusu kanun teklifinin hazırlanıp meclise gönderilmesi aşamasında aralarında Orman Mühendisleri Odası ve Türkiye Ormancılar Cemiyetinin de bulunduğu altı mesleki kuruluş ve STK ortak bir bildiri yayımlayarak teklife karşı çıkmıştır (Anonim, 1972). Ormancılık meslek kuruluşları ile birlikte bazı deneyimli hukukçular da benzer şekilde af yasası teklifinin sakıncalarına vurgu yapmışlardır (Usluoğlu, 1971; Börekçi, 1971). Ayrıca orman suçlarının affına ilişkin kanun teklifi çalışma ve tartışmalarının orman yangınlarını artırdığına ilişkin iddialar da ortaya atılmıştır (Abbasoğlu, 1973).

Anayasa değişikliğinin en önemli sonuçlarından biri de orman niteliğini kaybeden bazı orman alanlarının orman rejimi dışarısına çıkarılması konusudur. Millet Meclisi ve Cumhuriyet Senatosu görüşmelerinde bu konu hakkında da farklı görüşler dile getirilmiştir. Etkileri günümüze kadar gelen bu değişiklikle ilgili olarak da lehte ve aleyhte görüşler söz konusudur. Lehte görüşler genel olarak şu noktalarda toplanmaktadır: 663 Sayılı Yasa Anayasa Mahkemesi tarafından iptal edildiği için fiilen orman niteliğini kaybetmiş olan orman alanlarının orman köylüsünün kullanımına sunulmasının başka bir yolu bulunmamaktadır ve orman niteliğini kaybetmiş olan alanları ille de orman diyerek tutmak ulusal ekonomi açısından büyük kayıplara yol açacaktır. Eski tahdit haritalarını temel alarak belirlenen orman sınırları hatalı olduğu için köylünün kaybına yol açmıştır. Bu değişiklikle yıllardır tarımsal amaçlarla kullanılan ya da üzerinde köy kurulmuş olan, ancak orman sayılan dededen kalma topraklar sorunu kesin olarak çözülmüş olacaktır.

$\mathrm{Bu}$ değişikliğe karşı çıkan milletvekili ve senatörlerin vurguladıkları noktalar ise şöyle özetlenebilir: "Her şeyden önce bu değişiklik uygulanabilir değildir. Orman niteliğini kaybetmiş bir alanının Anayasa'nın yürürlüğe girdiği tarihten önce mi yoksa sonra mı orman niteliğini kaybettiğini saptamak mümkün değildir. $\mathrm{Bu}$ konu siyasi olarak istismar edilebilecek ve orman köylüsü yerine bu açıdan güçlü olanlar kazanacaktır. Anayasa devlete ormanları koruma ve genişletme görevi vermektedir. Bu değişiklik Anayasa'nın söz konusu hükmüne aykırıdır. İklim, su ve toprak rejimi açısından hassas olan alanlarda bu değişikliğin uygulanması giderilmesi olanaksız zararlar doğuracaktır.”

Gerçekten de orman niteliğini kaybetmiş olduğu gerekçesiyle orman rejimi dışına çıkarılan toprakların tarımsal amaçlarla kullanılması yoluyla hem orman köylülerinin sorunlarının çözüleceğini düşünmek hem de ulusal ekonominin kazançlı çıkacağını ummak bütünüyle bir yanılgıdan ibarettir. Arazi kullanımı açısından tarım alanları; meralar ve ormanlar aleyhine sürekli genişlemiş, ancak ne orman köylüsünün sorunları çözülebilmiş ne de ulusal ekonomi açısından anlamlı ilerlemeler kaydedilebilmiştir. Buna karşlık orman, funda ve makiliklerden elde edilen tarım topraklarında yetiştirilen kültür bitkileri; orman ve diğer doğal bitki formasyonlarının toprak koruma ve hidrolojik işlevlerini yerine getirememektedirler (Gülen vd., 1981). Örneğin, söz konusu dönemde yapılan çalışmalar, Türkiye'de seller nedeniyle meydana gelen zararların yıllık ekonomik maliyetinin 100 milyon TL civarında olduğunu; yalnızca 1955-1965 dönemi taşkınlarında 409 yurttaşın yaşamını kaybettiğini göstermektedir (Uslu, 1973).

Anayasa değişikliğinin gerçekleşmesinin ardından 1973 yılında çıkarılan 1744 Sayılı Yasa ile 6831 Sayılı Orman Yasası'nın 2. maddesi değiştirilerek anayasa değişikliğinin fiilen uygulanmasına başlanmıştır. Orman sınırlar dışına çıkarma işlemine yasal statü tanınması, ormansızlaşmanın temel nedeni olan açmacılık eyleminin devlet tarafinda kabul edilmesi ve affedilmesi şeklinde değerlendirilmiştir (Tolunay, 1988). Ne var ki, orman köylüsünün sorunları çözülmediği gibi orman tahripleri de son bulmamış ve 12 Eylül 1980 yılında gerçekleşen askeri darbenin ardından yürürlüğe giren 1982 Anayasası, orman niteliğini kaybetme zaman eşiğini 31.12.1981 tarihine taşımış; yani yaklaşık sonraki 20 yıllık zaman diliminde dahi tahrip edilmiş orman alanlarının orman rejimi dışına çıkarılması olanaklı hale gelmiştir. Bu düzenleme de orman tahriplerinin son bulmasını sağlamamış, orman tahripleri çeşitli yollarla devam etmiş ve tahrip edilen orman alanlarının orman rejimi dışına çıkarılması beklentisi, önceki uygulamalara bakarak sürüp gitmiş̧ir. Bu beklentinin bir sonucu olarak 2007 yılında iktidar partisi tarafından başlatılan yeni anayasa taslağı çalışmalarında zaman eşiği 23.07.2007 olarak yer almış, ancak dönemin siyasal koşulları gereği söz konusu anayasa çalışması rafa kaldırılmıştır (Erdönmez, 2013). Diğer yandan, 1995 yılında 2924 sayılı Orman Köylülerinin Kalkınmalarının Desteklenmesi Hakkında 
Yasa'nın 11. ve 12. maddeleri değiştirilmiş ve 1997 yılında Orman Köylülerinin Kalkınmalarının Desteklenmesi Hakkında Yönetmelik çıkarılarak, orman sınırları dışarısına çıkarılan alanların orman köylülerine satışı uygulaması ülke çapında başlamıştır. 2012 yılında çıkarılan 6292 Sayılı Orman Köylülerinin Desteklenmesi ve Hazine Adına Orman Sınırları Dışarısına Çıkarılan Yerlerin Değerlendirilmesi ile Hazineye Ait Tarım Arazilerinin Satışı Hakkında Kanun ile 2b alanlarının orman köylüsü olmayanlara satışı olanaklı hale getirilmiş; 1970 yılında orman köylüsünün sorunlarının çözümü gerekçesi ile başlayan süreç büyük ölçüde kentsel bir arazi rantı projesine dönüşmüştür.

Anayasa'da yapılan bu değişikliğin ardından 1973 yılında çıkarılan 1744 Sayılı Yasa ile uygulanmasına başlanılan ve kamuoyunda $2 \mathrm{~b}$ olarak bilinen, daha önceden ormanken orman niteliğini kaybettiği gerekçesiyle orman rejimi dıșına çıkarılan alanların toplamı 2019 yılı sonu itibariyle 620 bin hektara ulaşmıştır (OGM, 2020). Orman kadastro çalışmaları devam ettikçe bu miktar artacaktır. Örnek vermek gerekirse 2017 yılı sonunda toplam 2b alanı 535 bin 598 hektar iken 2018 yılı sonunda 580 bin hektara yükselmiştir. Yani, yaklaşık olarak her yıl 40 bin hektarlık yeni $2 \mathrm{~b}$ alanı tanımlanarak bu alanlar orman sınırları dışarısına çıkarılmaktadır.

Anayasa değişikliği görüşmeleri sırasında dördüncü fikrada yapılan ve devletle orman köylüsünün işbirliği yapmasını içeren değişiklik de oldukça fazla tartışılmıştır. Değişikliği savunanlar, böylelikle orman halk ilişkilerinin iyileşeceğini dile getirirken, karşı çıkanlar devlet orman işletmeciliği ilkesinin zarar göreceğine ilişkin kaygılarını ifade etmişlerdir. Ne var ki, anayasa değişikliğinin gerçekleşmesini izleyen süreçte bu değişikliğin yaşama geçirilmesine ilişkin somut bir adım atılmamış, değişiklik kâğıt üzerinde kalmıştır.

Burada vurgulanması gereken bir diğer önemli konu da Orman Mühendisleri Odası (OMO) ve Türkiye Ormancılar Derneği (TOD) gibi meslek kuruluşları ile dönemin tek orman fakültesi olan İstanbul Üniversitesi Orman Fakültesi (İÜOF)'nin tepkileri ile yasama organında söz konusu kurumlar tarafından gösterilen tepkilere gösterilen/gösterilmeyen itibardır. Demokratik yönetim anlayışının olmazsa olmazlarından biri de karar alma süreçlerinde ilgili kesimlerin görüs ve önerilerini dile getirmesi ve bu görüşlerin alınan kararlarda etkili olması gereğidir. Bu gerekliliğe gösterilen özen ne yazık ki 1970’li yıllardan çok daha geri durumdadır. OMO büyük ölçüde siyasallaşarak âdeta hükümetin bir yan kuruluşu gibi çalışmaktadır. Sayıları onlarla ifade edilir hale gelen orman fakülteleri ise 2010'lu yıllara kadar süren ve ormancılıkla ilgili önemli konuları gündemine alarak, akademik genel kurullarında demokratik yöntemlerle oluşturulan fakülte görüşlerini kamuoyu ile paylaşma anlayışını terk etmiştir. Sınırlı sayıdaki sivil toplum ve meslek kuruluşundan gelen tepkiler de yasama ve yürütme organı tarafından dikkate alınmamakta, ormancılıkla ilgili karar alma süreçleri dar bir halkanın dışına taşmamaktadır. 2017 yılında yapılan referandumla kabul edilip Haziran 2018'de yapılan seçimlerle uygulamaya geçen Cumhurbaşkanlığı Hükümet Sistemi, parlamentonun yetkilerinin kısıtlanması nedeniyle bu halkayı daha da daraltmıştır.

\section{Sonuç}

Türkiye yüzyıllar boyunca barındırdığı uygarlıkların ormanlar üzerindeki olumsuz etkileri sonucu geçmişten günümüze büyük orman kayıpları yaşamıştır. Yoğun nüfus, sosyo-ekonomik geri kalmışlık, kır-kent dengesinin kurulamamış olması gibi bazı kök etkenler nedeniyle ormanlar üzerindeki olumsuz baskı günümüzde de devam etmektedir. Siyaset kurumu bu baskıya karşı ormanları koruyucu önlemleri güçlendirmek yerine çoğu zaman ormanlardan taviz vermeyi ve bu yolla siyasal çıkar sağlamayı tercih etmektedir. Ormancılık tarihinde bu değerlendirmeye kanıt olarak gösterilebilecek en önemli olay 1970 yılında çıkarılan 1255 Sayılı Yasa ile 1961 Anayasası'nın ormancılıkla ilgili 131. maddesinin değiştirilmesidir. Millet Meclisi ve Senatoda temsil edilen bütün partilerin desteğiyle gerçekleşen bu değişikliğe Senatodaki en önemli itirazlar asker kökenli (siyaset kökenli olmayan) senatörlerden gelmiş; Millet Meclisinde ise özellikle ormancılık eğitimi almış ve ülke ormancılığının gerçeklerini yakından tanıyan bazı vekillerin sağduyulu konuşmaları diğer vekillerden alkış almışsa da, oylamada siyasi çıkarlara dayalı parti kararları ağır basmış ve anayasa değişikliği gerçekleşmiştir.

Aradan geçen 50 yılda, yapılan değişikliklerin ormancılık açısından hiçbir olumlu sonucu görülmemiş, tersine, özellikle $2 b$ konusunda sorunlar derinleşerek içinden ç1kılmaz bir sarmala dönüşmüştür. Buna rağmen siyasetormancılık ilişkisi, daha farklı bir söyleyişle siyaset kurumunun ormancılığa bakışı neredeyse hiç değişmemiş, ormanlar ve ormancılığın sorunlarına rasyonel çözümler üretmek yerine güncel ve geçici siyasal çıkarlar doğrultusunda ormancılığa yön verme arayışı süregelmiştir. Özellikle 1980'li yıllardan itibaren sürekli yapılan ve neredeyse tamamı ormanların aleyhine olan yasal düzenlemeler ile neye hizmet ettiği belli olmayan örgütsel düzenlemeler bu durumun açık göstergesidir. Yalnızca 2010 yılından sonraki 10 yıllık dönemde 6831 Sayılı Orman Yasası'nda 20 farklı değişiklik yapılmış; yine yalnızca 2011 yılında dört farklı değişiklik yapılarak adeta bir rekor kırılmıştır. Son olarak da 4 Kasım 2020 tarihinde yürürlüğe giren 7255 sayılı yasa ile sahipli arazilerde 
ekim ve dikim yoluyla oluşturulan orman alanları, orman alanı dışına çıkarılmış ve böylelikle söz konusu alanlarda yapılaşmasının önü açılmıştır. 1839 yılında ilk örgütü kurulan, 1857 yılında ilk eğitim kurumu açılan, 1870 yılında ilk yasal düzenlemesi yapılan Türkiye ormancılığının ve ormancılık politikasının bugün içinde bulunduğu olumsuzlukların temelinde yatan neden de, hiç kuşkusuz siyaset kurumunun ormancılığa dönük bu çarpık yaklaşımında aranmalıdır. 1970 yılında gerçekleştirilen anayasa değişikliği hem bu çarpıklığı açıklıkla gözler önüne sermesi açısından hem de sonraki dönemi yönlendirici etkisi bakımından Türkiye’de ulusal ormancılık politikasının tarihsel gelişim sürecinde önemli bir dönüm noktası oluşturmuştur.

Siyaset kurumunun ormancılığa yönelik bu olumsuz yaklaşımı devam ederken, ormancılık politikasının en önemli aktörlerinden olan bilim kuruluşları ve meslek örgütlerinin yaklaşımlarında ise ciddi değişimler gözlenmektedir. 1970'li yıllarda meslek örgütleri ve bilim kuruluşlarının ormancılık politikası ile ilgili kararların alınması sürecinde çok daha aktif olduklarını ve siyasetten bağımsız olarak, ormanların korunması ve sürekliliğini amaç edindikleri görülmektedir. Günümüzde ise bilim kuruluşları, yani orman fakülteleri politikaların şekillendirilmesinde kendi rolünü unutmuş, akademisyenler pasifleşmiş, ana meslek örgütü olan Orman Mühendisleri Odası ise bütünüyle siyasileşmiş, rasyonel ve akılcı kararlarla ormanların ve ormancıların çıkarlarını desteklemek yerine, siyasi taraf olma güdüleriyle akılcılıktan uzaklaşmıştır. TOD ise bir ölçüde de olsa etkililiğini devam ettirmekte, ancak yetersiz kalmaktadır. Buna karşılık, 1970'li yıllarda neredeyse yok düzeyinde olan yerel halk örgütlenmeleri ormanlara zarar veren girişimlerle mücadelede en önemli unsur haline gelmiş, ülke ve yöre bazında çalışan STK'lar güçlenmiş ve etkisini artırmıştır. Ne var ki yerel halk örgütlenmeleri ve STK'lar ormancılık politikalarının şekillenmesinde etkili olamamaktadır. Bu noktada bilim kuruluşları ile bilim adamlarının ve meslek örgütlerinin rolü yadsınamaz. Bu nedenle, önümüzdeki süreç, ulusal ormancılık politikalarının şekillenmesi açısından bilim kuruluşlarının ve meslek örgütlerinin izleyeceği yol ile yakından ilişkilidir.

Ormancılık politikalarının sonuçları kısa ve orta vadeden çok uzun vadede ortaya çıkar. Bu nedenle, ulusal ormancılık politikalarının şekillendirilmesinde günlük siyasi çıkarların etkisinin minimuma indirilmesi zorunludur. 1970 yılında yapılan anayasa değişikliğinin olumsuz etkileri, aradan 50 yıl geçmiş olmasına karşın bugün hala sürmektedir. Bu nedenle, ormancılık politikası araştırmalarının da aynı perspektife sahip olması, kısa dönem sonuçlar üzerine odaklanmak yerine uzun vadeli analizlerin tercih edilmesi bir zorunluluktur.

\section{Kaynaklar}

1. Abbasoğlu, Ş. (1965). Belirtme çalışmaları ve ötesi. Orman Mühendisliği 4 (4), 7-11.

2. Abbasoğlu, Ş. (1973). Orman suçlarının affı ile orman yangınları arasındaki ilişki. Orman Mühendisliği 12 (9), 1-3.

3. Akesen A., Ekizoğlu, A. (2010) Ormancılık Politikası. Orman. (Ed. Aytuğ AKESEN ve Abdi EKİZOĞLU). TOD Eğitim Dizisi Yayın No: 6, Sayfa: 1-17, Ankara.

4. Akesen, A., Ekizoğlu, A., Kuvan, Y., Atmış,E. (2010) Ormancılık Politikası. Ormancılık Politikası ed: Akesen A., Ekizoğlu, A., Türkiye Ormancilar Derneği Eğitim Dizisi Yayın No: 6, Özdoğan Matbaa, Ankara, 37-63.

5. Akıncı, A., Usta, S. (2015). Türkiye'de çok partili hayata geçişte etkili olan iç faktörlerin analizi. KMÜ Sosyal ve Ekonomik Araştırmalar Dergisi 17 (29), 41-52.

6. Anonim (1964). Halk orman münasebetlerine ait görüşlerimiz. Orman Mühendisliği 3(3), 3-5.

7. Anonim (1965a). Cumhurbaşkanlığı yüce katına. Orman Mühendisliği 4 (4), 5-6.

8. Anonim (1965b). Ormanlarla İlgili Kanun Tasarısı ve teklifleri hakkında odamız görüşü. Orman Mühendisliği 4 (1), 39-43.

9. Anonim (1967). Türkiye Ormancılar Cemiyeti ile Orman Mühendisleri Odası'nın 24.4.1967 günü basına ve TRT'ye aksettirilen ortak bildirisi. Orman ve Av 39 (4), 1.

10. Anonim (1972). Türkiye Ormancılar Cemiyeti, TMMOB Orman Mühendisleri Odası, Türkiye Tabiatını Koruma Cemiyeti, Yeşil Türkiye Ormancılar Cemiyeti, Türkiye Orman Teknikerleri Cemiyeti, Orman Memurları ve Orman Sevenler Cemiyeti Kuruluşlarının Bazı orman suçlarının affına ve bunlardan mütevellit idare şahsi haklarının düşürülmesine dair kanun teklifi hakkındaki görüşleri. Orman ve Av 45 (2), 4-5.

11. Bingöl, İ. (1990). Geçmişten Günümüze Ormanlarımız ve Ormancılı̆̆ımız. Ormancılık Eğitim ve Kültür Vakfi Yayın No. 4: İstanbul, 157 pages. 
12. Börekçi, M. (1971). Orman suçlarının affi: Kara talih. Orman ve Av 44 (4), 7-9.

13. Börklüoğlu, L. (2017). 27 Mayıs askeri darbesi sonrasında ordu içinde iktidar mücadelesi: Milli Birlik Komitesi ve Silahlı Kuvvetler Birliği. Osmaniye Korkut Ata Üniversitesiİktisadi ve İdari Bilimler Fakültesi Dergisi 1 (2), 13-28.

14. Çepni, S. (2018). Araştırma ve Proje Çalışmalarına Giriş. PEGEM, Trabzon, 447 pages.

15. Diker, M. (1947). Türkiye'de Ormancılık. Dün-Bugün-Yarın. TC Tarım Bakanlığı Orman Genel Müdürlüğü Yayınları Sayı 61. Akın Matbaası, Ankara. 132 pages.

16. Diker, M., Savaş, K. (1947). Yurdda Orman Azalması. TC Tarım Bakanlığı Orman Genel Müdürlüğü Yayınlarından Sayı 73: Ankara, 31 pages.

17. DPT (1972). Üçüncü Beş Yıllık Kalkınma Planı Ormancılık Özel İhtisas Komisyonu Raporu. DPT Yayın No: 1174, Ankara. 150 pages.

18. Emiroğlu, A. (2011). 27 Mayıs 1960 İhtilali ve Demokrat Parti’nin tasfiyesi. Selçuk Üniversitesi Kdınham Faik İçil Meslek Yüksekokulu Sosyal ve Teknik Araştırmalar Dergisi 1 (1), 13-27.

19. Erdönmez, C. (1994). Türkiye'de Kırsal Kalkınma. Türkiye 1. Tarım Ekonomisi Kongresi, 88-97. 8-9 Eylül 1994, İzmir.

20.Erdönmez, C. (2013). 2B alanlarının satışının Türkiye Ulusal Ormancılık Programı açısından irdelenmesi. Kastamonu Üniversitesi Orman Fakültesi Dergisi 13 (2): 307-324.

21. Erdönmez, C. (2020). Yanan ormanlarda 50 gün: Yaşar Kemal'in gözleminden ormancılık dersleri. Bartın Orman Fakültesi Dergisi 22 (2). DOI: 10.24011/barofd.744987

22. Erdönmez, C., Atmış, E., Özden, S. (2010). Ormancılık Politikası. Türkiye'de Ormancılık Politikası. ed: Akesen A., Ekizoğlu, A., Türkiye Ormancılar Derneği Eğitim Dizisi Yayın No: 6, Özdoğan Matbaa, Ankara, 101-143.

23. Gülen, İ., Balcı, N., Özdönmez, M. (1981). Türkiye'de arazi kullanma sorunları ve ormanlar. Istanbul Üniversitesi Orman Fakültesi Dergisi B Serisi 31 (1): 15-24.

24. Gülen, İ., Özdönmez, M. (1981) Türkiye'de Orman ve Ormancılık. İstanbul Üniversitesi Orman Fakültesi Dergisi, Seri B 31(2): 1-18.

25. Gümüsş, C. (2004). Ormancılık Politikası. Karadeniz Teknik Üniversitesi Orman Fakültesi, Fakülte Yayın No: 34, Trabzon, 444 pages.

26. Gümüş, C. (2018) Türk Orman Devrimi. Türkiye Ormancılar Derneği , Düzmez Ofset, Ankara, 306 pages.

27. Günşen, H.B., Atmiş, E. (2015). İç göçlerin orman köylerinde ve ormancılık çalışmaları üzerindeki etkisi. IV. Ormancılıkta Sosyo-Ekonomik Sorunlar Kongresi, 15-17 Ekim 2015, Trabzon. Bildiriler Kitab1, 177-190.

28. İnal, S. (1959). Türkiye Ormancılığının Ana Savası. Türkiye Ticaret Odaları, Sanayi Odaları ve Ticaret Borsaları Birliği Matbaası, Ankara. 38 pages.

29. İnal, S. (1971). Türkiye'de Anayasa Ormancılık İlişkileri. İstanbul Üniversitesi Orman Fakültesi Yayını 171/1647: İstanbul, 176 pages.

30. Kanca, O.C. (2012). 1950-1960 arası Türkiye'de uygulanan sosyo-ekonomik politikalar. Mustafa Kemal Üniversitesi Sosyal Bilimler Enstitüsü Dergisi 9 (19): 47-63.

31. Keyman, S. (1965). Türk Hukukunda Af (Genel Af-Özel Af). Ankara Üniversitesi Hukuk Fakültesi Yayınları No: 199. 156 pages.

32. Kıral , B. (2020). Nitel bir veri analizi yöntemi olarak doküman analizi. Siirt Üniversitesi Sosyal Bilimler Enstitüsü Dergisi 15: 170-189.

33. Koçtürk, O.M., Gölalan, M. (2010). 1923-1950 Türkiye ekonomisinin yapısal analizi. Üçüncü Sektör Kooperatifçilik 45 (2), 48-65.

34. Konukçu, M. (1999). Ormancılığımız: Turkish Forestry. Devlet Planlama Teşkilatı Yayını, Ankara.

35. OGM (1963). Birinci Beş Yıllık Ormancılık Kalkınma Plânı. OGM Yayınları Seri No: 3, Sıra No: 373 , Ankara. 99 pages.

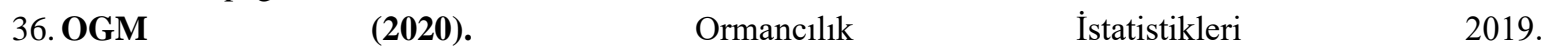
https://www.ogm.gov.tr/ekutuphane/Istatistikler/Forms/AllItems.aspx?RootFolder=\%2Fekutuphane\%2FIs tatistikler\%2FOrmanc\%C4\%B11\%C4\%B1k\%20\%C4\%B0statistikleri\&FolderCTID=0x012000301D182F 8CB9FC49963274E712A2DC00\&View $=\{$ C19AB316-F6A1-40F4-BE44-7526AE967FDC $\}$

(27.08.2020). 
37. Özdönmez, M. (1965). Türkiye’de Orman Suçları nevileri, Sebepleri ve Önlenmesi Çareleri Üzerine Araştırmalar. Tarım Bakanlığı Orman Genel Müdürlüğü Yayını, Yayın No. 422: İstanbul, 156 pages.

38. Özdönmez, M. (1973a). Orman suçları ile ilgili af kanunları ve sonuçları. İstanbul Üniversitesi Orman Fakültesi Dergisi B23 (2), 48-61.

39. Özdönmez, M. (1973b). Devlet ormanlarından köylülerin faydalanma hakları. İstanbul Üniversitesi Orman Fakültesi Dergisi B23 (2), 62-77.

40. Özdönmez, M., İstanbullu, T., Akesen, A., Ekizoğlu, A. (1996). Ormancilık Politikas1. İstanbul Üniversitesi, Üniversite Yayın No: 3968, Fakülte Yayın No: 435, İ̈̈ Basımevi, İstanbul, 416 pages.

41. Öztürk, Ş. (2008). Kırsal yoksulluk ve neoliberal ekonomi politikaları. Uluslararası Sosyal Araştırmalar Dergisi 1 (5), 605-634.

42. Sertbaş, N. (1965). Geçici 6. madde. Orman ve Av 37 (6), 1-2.

43. TBMM, (1970a). Millet Meclisi Tutanak Dergisi, Dönem 3, Cilt 4, Toplantı 1, 68'nci Birleşim, 13.4.1970 Pazartesi.

44. TBMM, (1970b). Cumhuriyet Senatosu Tutanak Dergisi, Cilt 57, Toplantı 9, 60'ncı Birleşim, 16.4.1970.

45. Toksoy, D., Ayaz, H., Şen, G., Özden, S. (2005) Doğa Karadeniz Bölgesinde Orman-Köylü İlişkileri. Kafkas Üniversitesi Artvin Orman Fakültesi Dergisi, 6 (1-2): 79-85

46. Tolunay, A. (1988). Sosyal Ormancılık ve Türkiye Açısından Önemi. Basılmamış Doktora Tezi. İstanbul Üniversitesi, Fen Bilimleri Enstitüsü.

47. Uslu, S. (1973). Türkiye'de orman tahribatı ve doğurduğu problemler. İstanbul Üniversitesi Orman Fakültesi Dergisi B23 (2): 40-47.

48. Usluoğlu, H.A. (1971). Orman suçlarının affına ilişkin kanun tasarısı. Orman ve Av 44 (2), 1-2.

49. Üçüncü, N. (1970). Orman Mühendisleri Odası XVI. Genel Kurul Açış Konuşması. Orman Mühendisliği 9 (4): 3-6.

50. Yıldırım, A., Şimşek, H. (2013). Sosyal bilimlerde nitel araştırma yöntemleri. Ankara: Seçkin Yayıncılık, Ankara, 446 pages. 